\title{
Article
}

\section{Elemental Analysis and In Vitro Evaluation of Antibacterial and Antifungal Activities of Usnea barbata (L.) Weber ex F.H. Wigg from Călimani Mountains, Romania}

\author{
Violeta Popovici ${ }^{1}\left(\mathbb{D}\right.$, Laura Bucur ${ }^{2, *}$, Suzana Ioana Calcan ${ }^{3}$, Elena Iulia Cucolea ${ }^{3}$, Teodor Costache ${ }^{3}{ }^{\circledR}$, \\ Dan Rambu ${ }^{3}$, Verginica Schröder $\left.{ }^{4}{ }^{(}\right)$, Cerasela Elena Gîrd ${ }^{5}\left(\mathbb{D}\right.$, Daniela Gherghel ${ }^{6}$, Gabriela Vochita ${ }^{6}$, \\ Aureliana Caraiane ${ }^{7}$ and Victoria Badea ${ }^{1}$
}

1 Department of Microbiology and Immunology, Faculty of Dental Medicine, Ovidius University of Constanta, 7 Ilarie Voronca Street, 900684 Constanta, Romania; violeta.popovici@365.univ-ovidius.ro (V.P.); victoria.badea@365.univ-ovidius.ro (V.B.)

2 Department of Pharmacognosy, Faculty of Pharmacy, Ovidius University of Constanta, 6 Capitan Al. Serbanescu Street, 900001 Constanta, Romania

3 Research Center for Instrumental Analysis SCIENT, 1E Petre Ispirescu Street, 077167 Tancabesti, Romania; suzana.calcan@scient.ro (S.I.C.); iulia.cucolea@scient.ro (E.I.C.); teodor.costache@scient.ro (T.C.); dan.rambu@scient.ro (D.R.)

4 Department of Cellular and Molecular Biology, Faculty of Pharmacy, Ovidius University of Constanta, 6 Capitan Al. Serbanescu Street, 900001 Constanta, Romania; verginica.schroder@univ-ovidius.ro

5 Department of Pharmacognosy, Phytochemistry, and Phytotherapy, Faculty of Pharmacy, Carol Davila University of Medicine and Pharmacy, 6 Traian Vuia Street, 020956 Bucharest, Romania; cerasela.gird@umfcd.ro

check for updates

Citation: Popovici, V.; Bucur, L.; Calcan, S.I.; Cucolea, E.I.; Costache, T.; Rambu, D.; Schröder, V.; Gîrd, C.E.; Gherghel, D.; Vochita, G.; et al Elemental Analysis and In Vitro Evaluation of Antibacterial and Antifungal Activities of Usnea barbata (L.) Weber ex F.H. Wigg from Călimani Mountains, Romania. Plants 2022, 11, 32. https://doi.org/ 10.3390/plants11010032

Academic Editors: Martin Backor, Michal Goga and Dajana Ručová

Received: 23 November 2021 Accepted: 21 December 2021 Published: 23 December 2021

Publisher's Note: MDPI stays neutral with regard to jurisdictional claims in published maps and institutional affiliations.

Copyright: (C) 2021 by the authors. Licensee MDPI, Basel, Switzerland. This article is an open access article distributed under the terms and conditions of the Creative Commons Attribution (CC BY) license (https:// creativecommons.org/licenses/by/ $4.0 /)$.
6 NIRDBS, Institute of Biological Research Iasi, 47 Lascar Catargi Street, 700107 Iasi, Romania; daniela.gherghel@icbiasi.ro (D.G.); gabriela.vochita@icbiasi.ro (G.V.)

7 Department of Oral Rehabilitation, Faculty of Dental Medicine, Ovidius University of Constanta, 7 Ilarie Voronca Street, 900684 Constanta, Romania; aureliana.caraiane@365.univ-ovidius.ro

* Correspondence: laurabucur@univ-ovidius.ro; Tel.: +40-721528446

Abstract: This study aims to complete our research on Usnea barbata (L.) Weber ex F.H. Wigg (U. barbata) from the Călimani Mountains, Romania, with an elemental analysis and to explore its antibacterial and antifungal potential. Thus, we analyzed twenty-three metals ( $\mathrm{Ca}, \mathrm{Fe}, \mathrm{Mg}, \mathrm{Mn}, \mathrm{Zn}$, $\mathrm{Al}, \mathrm{Ag}, \mathrm{Ba}, \mathrm{Co}, \mathrm{Cr}, \mathrm{Cu}, \mathrm{Li}, \mathrm{Ni}, \mathrm{Tl}, \mathrm{V}, \mathrm{Mo}, \mathrm{Pd}, \mathrm{Pt}, \mathrm{Sb}, \mathrm{As}, \mathrm{Pb}, \mathrm{Cd}$, and $\mathrm{Hg}$ ) in dried U. barbata lichen (dUB) by inductively coupled plasma mass spectrometry (ICP-MS). For the second study, we performed dried lichen extraction with five different solvents (ethyl acetate, acetone, ethanol, methanol, and water), obtaining five $U$. barbata dry extracts (UBDE). Then, using an adapted disc diffusion method (DDM), we examined their antimicrobial activity against seven bacterial species-four Gram-positive (Staphylococcus aureus, Enterococcus casseliflavus, Streptococcus pyogenes, and Streptococcus pneumoniae) and three Gram-negative (Escherichia coli, Klebsiella pneumoniae, and Pseudomonas aeruginosa)—and two fungi species (Candida albicans and Candida parapsilosis). Usnic acid (UA) was used as a positive control. The ICP-MS data showed a considerable Ca content $(979.766 \mu \mathrm{g} / \mathrm{g})$, followed by, in decreasing order, $\mathrm{Mg}, \mathrm{Mn}, \mathrm{Al}, \mathrm{Fe}$, and $\mathrm{Zn}$. Other elements had low levels: $\mathrm{Ba}, \mathrm{Cu}, \mathrm{Pb}$, and $\mathrm{Cr}(3.782-1.002 \mu \mathrm{g} / \mathrm{g})$; insignificant amounts $(<1 \mu \mathrm{g} / \mathrm{g})$ of $\mathrm{Hg}$ and $\mathrm{V}$ were also found in dUB. The trace elements Ag, As, $\mathrm{Cd}, \mathrm{Co}, \mathrm{Li}, \mathrm{Tl}, \mathrm{Mo}, \mathrm{Pd}, \mathrm{Pt}$, and $\mathrm{Sb}$ were below detection limits $(<0.1 \mu \mathrm{g} / \mathrm{g})$. The DDM resultsexpressed as the size $(\mathrm{mm})$ of the inhibition zone diameter (IZs) - proved that the water extract did not have any inhibitory activity on any pathogens $(\mathrm{IZs}=0 \mathrm{~mm})$. Gram-positive bacteria displayed the most significant susceptibility to all other UBDE, with Enterococcus casseliflavus showing the highest level (IZs = 20-22 mm). The most susceptible Gram-negative bacterium was Pseudomonas aeruginosa $(\mathrm{IZs}=16-20 \mathrm{~mm})$; the others were insensitive to all $U$. barbata dry extracts (IZs $=0 \mathrm{~mm})$. The inhibitory activity of UBDE and UA on Candida albicans was slightly higher than on Candida parapsilosis.

Keywords: Usnea barbata (L.) Weber ex F.H. Wigg; elemental analysis; metals; antibacterial activity; antifungal activity; disc diffusion method; usnic acid; polyphenols; tannins 


\section{Introduction}

Plants have been used in ethnomedicine since ancient times due to their numerous pharmacological activities. Over the years, the benefits of various plant extracts and natural compounds to maintain good health status, prevent disease, and ameliorate different pathologies have been confirmed [1]. The Traditional Medicine Division of the World Health Organization [2] highlights that the thousand-year-old use of medicinal plants as therapeutic resources should be considered due to their efficacy [3].

In the large world of plants, lichens are symbiotic organisms involving a fungus (mycobiont) and autotrophic partner-alga or cyanobacteria (photobiont) [4]. Photobionts are surrounded by mycobiont hyphae, which constitute around $90 \%$ of the total thallus biomass; structurally and functionally, this association is very different from free-living algae/cyanobacteria and fungi [5]. In lichen symbiosis, the mycobiont provides a suitable environment for the photobiont's growth and for protection against intense irradiation, microorganisms, and herbivores. Besides a wide range of specific organic compounds (known as lichen secondary metabolites [6] with various bioactivities [7]), a mycobiont supports photobiont metabolism, assuring its required minerals [4]. Lichens' mineral nutrition mainly depends on atmospheric sources and has limited water and gas exchange [8]. These characteristics make them significant air pollution biomonitors $[9,10]$ or environmental risk detectors $[11,12]$. The lichen thallus effectively absorbs minerals from wet and dry atmospheres [13]; it also contains metal particles from various substrates [14,15]. The minerals' distribution within lichen thalli is not homogenous and depends on their morphological properties [4]. Thus, photobionts retain only the metals used for their metabolic processes ( $\mathrm{Ca}, \mathrm{Mg}, \mathrm{Co}, \mathrm{Cu}, \mathrm{Fe}, \mathrm{Mn}, \mathrm{Mo}, \mathrm{Ni}, \mathrm{V}$, and $\mathrm{Zn}$ ) [16]. These metals have various roles in maintaining lichen homeostasis.

In addition to the metals required for photobiont survival and assuring metabolic processes, lichens can accumulate and retain many heavy and trace metals in quantities that vastly exceed their physiological requirements. They tolerate these high metal concentrations by sequestrating metals in the extracellular space as oxalate crystals, after the mycobiont's production of organic short-chain acids (oxalic, citric, and malic) [17]. Complexing them with the lichen's secondary metabolites, such as phenolic acids [18] (depsides, depsidones [19], and dibenzofurans [20]), leads to another storage form of metals in this space.

Heavy and trace metals in the lichens' photobionts generate metal stress by diminishing chlorophyll, photosynthesis rate, photosystem II (PS II) quantum yield, and inducing changes at the cellular and tissue levels [21]. They are often involved in oxidative stress by generating reactive oxygen species (ROS) [22]. Therefore, excess metals must be excluded from the cytosol and removed through efflux or compartmentalization to preserve normal metabolic functioning. Antioxidants, phytochelatins transporting metals to the extracellular space, and metallothioneins with metal-binding properties [21] represent lichens' most known defense mechanisms.

Lichens' secondary metabolites also have numerous bioactivities: antioxidant, antiinflammatory, anticancer, cytotoxic, antigenotoxic, antimutagenic, antibacterial, antifungal, and antiviral $[23,24]$. Nowadays, these specific natural compounds display significant roles in modern drug development, especially for antimicrobial agents, due to a significant emergence of multidrug-resistant (MDR) pathogenic microorganisms. The evolution of multidrug antimicrobial resistance in commensal bacteria [25] has become a prominent public health concern. Therefore, the progressive loss of efficacy of conventional antiinfective treatments represents a high challenge for herbal medicine to develop drugs with a broad spectrum of antimicrobial activity and lower side effects [26].

Deciphering the antibiotic resistance mechanisms developed in pathogenic microorganisms, Blanco et al. (2016) described two principal ways of acquiring resistance: reduction of the microbial affinity for the antibiotic (mutations in genes encoding the antimicrobial targets) or diminution of the active concentration of the antibiotic inside the cell [27]. For the second pathway, they tried to classify the biochemical mechanisms of MDR into three 
categories: production of hydrolytic or modifying enzymes; mutations in the antibiotics' transporters, impeding their cell penetration; and energy-dependent efflux pumps to extrude the antibiotics, blocking their access to the target and also generating cross-resistance to numerous antimicrobial drugs [27]. Furthermore, they proved that various MDR efflux pumps exist in Gram-positive bacteria (Staphylococcus aureus and Streptococcus pneumoniae), Gram-negative bacteria (Pseudomonas aeruginosa and Escherichia coli), and fungi (Candida albicans) [27]. Furthermore, Streptococcus pyogenes [28], Enterococcus casseliflavus [29,30], Klebsiella pneumoniae [31,32], and Candida parapsilosis [33] were also included in MDR pathogens, according to other studies.

Many researchers proved that the extracts of Usnea lichens in different solvents had inhibitory activity on pathogens known for antimicrobial resistance [34,35]. As a representative of the Usnea genus, $U$. barbata has been used for thousands of years to treat various diseases, including infectious ones [36]. Its phytochemical profile [37] displays bioactive secondary metabolites as specific phenolic compounds (depsides and depsidones), dibenzofurans (usnic acid) [38,39], and diphenyl ethers [40,41]; various representatives of these structural categories proved to have significant antibacterial and antifungal properties.

Recently, a research team examined $U$. barbata as a biomonitor of element deposition in the southern Patagonian forest connected with the Puyehue volcanic event [42]. Our study proposes an ICP-MS analysis for 23 metals on $U$. barbata native lichen from an unpolluted forest zone of volcanic mountains (Călimani Mountains, Suceava County, Romania). This lichen species was harvested from a coniferous forest in a peat bog zone with acid soil; it is important to mention that the $U$. barbata habitat zone is one of Romania's richest natural peat areas [43].

Using an agar diffusion method, another previous study using acetone extracts of six Usnea sp. investigated their antimicrobial effects against seven bacterial species [44]. Using the green chemistry concept, we obtained five UBDE in "preferable" solvents-acetone (UBA), ethyl acetate (UBEA), methanol (UBM), ethanol (UBE), and water (UBW) [45,46]and evaluated their antibacterial and antifungal properties on seven bacterial and two fungal species by an adapted disc diffusion method. Then, the obtained results were analyzed in correlation with the phytoconstituents of each $U$. barbata dry extract.

\section{Results}

\subsection{Elemental Analysis}

Twenty-three metals were analyzed in dried $U$. barbata lichen, and only thirteen elements were detected; the content of ten of the metals was below the quantification limit (LOQ) value. The LOQ values were in the range of $0.1-5.0 \mu \mathrm{g} / \mathrm{g}$. Five elements had $\mathrm{LOQ}=5 \mu \mathrm{g} / \mathrm{g}(\mathrm{Ca}, \mathrm{Fe}, \mathrm{Mg}, \mathrm{Mn}$, and $\mathrm{Zn})$, one element $(\mathrm{Al}) \mathrm{had} \mathrm{LOQ}=1.0 \mu \mathrm{g} / \mathrm{g}$, and seventeen others had LOQ $=0.1 \mu \mathrm{g} / \mathrm{g}$. The obtained results are summarized in Table 1 . Other detailed data were added in the Supplementary Material.

The dried lichen showed a significant calcium (Ca) content $(979.766 \pm 12.285 \mu \mathrm{g} / \mathrm{g})$, followed in decreasing order by magnesium $(\mathrm{Mg}, 172.721 \pm 0.647 \mu \mathrm{g} / \mathrm{g})$, manganese $(\mathrm{Mn}$, $101.425 \pm 1.423 \mu \mathrm{g} / \mathrm{g})$, aluminum (Al, $87.879 \pm 1.152 \mu \mathrm{g} / \mathrm{g})$, iron $(\mathrm{Fe}, 52.561 \pm 2.582 \mu \mathrm{g} / \mathrm{g})$, and zinc (Zn, 20,536 $\pm 0.125 \mu \mathrm{g} / \mathrm{g})$.

Other elements, such as barium (Ba, $3.782 \pm 0.052 \mu \mathrm{g} / \mathrm{g})$, copper $(\mathrm{Cu}, 1.523 \pm 0.013 \mu \mathrm{g} / \mathrm{g})$, lead $(\mathrm{Pb}, 1.296 \pm 0.007 \mu \mathrm{g} / \mathrm{g})$, and chromium $(\mathrm{Cr}, 1.002 \pm 0.008 \mu \mathrm{g} / \mathrm{g})$ had low levels; mercury $(\mathrm{Hg}, 0.671 \pm 0.020 \mu \mathrm{g} / \mathrm{g})$, nickel $(\mathrm{Ni}, 0.449 \pm 0.011 \mu \mathrm{g} / \mathrm{g})$, and vanadium $(\mathrm{V}$, $0.241 \pm 0.004 \mu \mathrm{g} / \mathrm{g}$ ) were present in insignificant amounts in dUB (Table 1).

Finally, data summarized in Table 1 show that ten elements-silver (Ag), arsenic (As), cadmium $(\mathrm{Cd})$, cobalt $(\mathrm{Co})$, lithium $(\mathrm{Li})$, thallium $(\mathrm{Tl})$, molybdenum $(\mathrm{Mo})$, palladium $(\mathrm{Pd})$, platinum $(\mathrm{Pt})$, and antimony $(\mathrm{Sb})$ - were non-detected; their content $(\mu \mathrm{g} / \mathrm{g})$ was lower than the quantification limit (LOQ) value $(<0.100 \mu \mathrm{g} / \mathrm{g})$.

The spike recovery (\%) values for all elements were included in the admissible range of $70-150 \%$, proving the specificity of our ICP-MS analysis (Table S1, Supplementary Material). 
Table 1. Mineral composition of Usnea barbata (L.) Weber ex F.H. Wigg dried lichen.

\begin{tabular}{ccc}
\hline Element & Content $(\mu \mathbf{g} / \mathbf{g})$ & LOQ $(\mu \mathbf{g} / \mathbf{g})$ \\
\hline $\mathrm{Ag}$ & $\mathrm{ND}$ & 0.100 \\
$\mathrm{Al}$ & $87.879 \pm 1.152$ & 1.000 \\
$\mathrm{As}$ & $\mathrm{ND}$ & 0.100 \\
$\mathrm{Ba}$ & $3.782 \pm 0.052$ & 0.100 \\
$\mathrm{Ca}$ & $979.766 \pm 12.285$ & 5.000 \\
$\mathrm{Cd}$ & $\mathrm{ND}$ & 0.100 \\
$\mathrm{Co}$ & $\mathrm{ND}$ & 0.100 \\
$\mathrm{Cr}$ & $1.002 \pm 0.008$ & 0.100 \\
$\mathrm{Cu}$ & $1.523 \pm 0.013$ & 0.100 \\
$\mathrm{Fe}$ & $52.561 \pm 2.582$ & 5.000 \\
$\mathrm{Li}$ & $\mathrm{ND}$ & 0.100 \\
$\mathrm{Mg}$ & $172.721 \pm 0.647$ & 5.000 \\
$\mathrm{Mn}$ & $101.425 \pm 1.423$ & 5.000 \\
$\mathrm{Ni}$ & $0.449 \pm 0.011$ & 0.100 \\
$\mathrm{~Pb}$ & $1.296 \pm 0.007$ & 0.100 \\
$\mathrm{Tl}$ & $\mathrm{ND}$ & 0.100 \\
$\mathrm{~V}$ & $0.241 \pm 0.004$ & 0.100 \\
$\mathrm{Zn}$ & $20.536 \pm 0.125$ & 5.000 \\
$\mathrm{Hg}$ & $0.671 \pm 0.020$ & 0.100 \\
$\mathrm{Mo}$ & $\mathrm{ND}$ & 0.100 \\
$\mathrm{Pd}$ & $\mathrm{ND}$ & 0.100 \\
$\mathrm{Pt}$ & $\mathrm{ND}$ & 0.100 \\
$\mathrm{Sb}$ & $\mathrm{ND}$ & 0.100
\end{tabular}

The analysis was performed in triplicate. Results are presented as mean \pm standard deviation (SD). LOQquantification limit $(\mu \mathrm{g} / \mathrm{g})$; $\mathrm{ND}$-non-detected, $\mathrm{Ag}$ - silver, $\mathrm{Al}$-aluminum, $\mathrm{As}$-arsenic, Ba-barium, $\mathrm{Ca}$ calcium, $\mathrm{Cd}$-cadmium, $\mathrm{Co}$-cobalt, $\mathrm{Cr}$-chromium, $\mathrm{Cu}$-copper, $\mathrm{Fe}$-iron, $\mathrm{Li}$-lithium, $\mathrm{Mg}$-magnesium, $\mathrm{Mn}-$ manganese, $\mathrm{Ni}$-nickel, $\mathrm{Pb}$-lead, $\mathrm{Tl}$-thallium, $\mathrm{Zn}$-zinc, $\mathrm{Hg}$-mercury, Mo-molybdenum, $\mathrm{Pd}$-palladium, $\mathrm{Pt}$ - platinum, $\mathrm{Sb}$ - antimony.

\subsection{Characterization of Usnea barbata (L.) Weber ex F.H. Wigg Dry Extracts}

The results obtained in our previous studies [46] performed on all five $U$. barbata dry extracts allow the characterization and comparative analysis of these extracts, both in terms of extraction conditions and the content of secondary metabolites (Table 2) correlated with the used solvents.

Table 2. Extraction conditions and secondary metabolite content of various dry extracts of Usnea barbata (L.) Weber ex F.H. Wigg.

\begin{tabular}{ccccccc}
\hline UBDE & Solvent & $\begin{array}{c}\text { Temperature of } \\
\text { Extraction }\left({ }^{\circ} \mathbf{C}\right)\end{array}$ & Yield \% & $\begin{array}{c}\text { UAC } \\
\text { (mg/g UBDE) }\end{array}$ & $\begin{array}{c}\text { TPC } \\
\text { (mgPyE/g UBDE) }\end{array}$ & $\begin{array}{c}\text { TC } \\
\text { (mg PyE/g UBDE) }\end{array}$ \\
\hline UBEA & Ethyl acetate & $75-80$ & 6.27 & 376.73 & 42.40 & 24.4 \\
UBA & Acetone & $55-60$ & 6.36 & 282.78 & 101.09 & 3.85 \\
UBE & Ethanol & $75-80$ & 12.52 & 127.21 & 67.30 & 70.70 \\
UBM & Methanol & 65 & 11.29 & 137.60 & 40.70 & 9.99 \\
UBW & Water & $95-100$ & 1.98 & 0.00 & 45.80 & 1.31 \\
\hline
\end{tabular}

UBDE-U. barbata dry extracts, UBEA-U. barbata dry extract in ethyl acetate, UBA-U. barbata dry extract in acetone, UBE-U. barbata dry extract in ethanol, UBM-U. barbata dry extract in methanol, UBW-U. barbata dry extract in water, UAC-usnic acid content, TPC - total polyphenol content, TC - tannin content, $\mathrm{mg}$ PyE/g UBDE-mg equivalents of pyrogallol per g UBDE.

Data from Table 2 show that dried lichen extraction in both alcohols (ethanol and methanol) had the highest yields- $12.52 \%$ and $11.29 \%$, respectively, followed by, in decreasing order, acetone $(6.36 \%)$ and ethyl acetate $(6.27 \%)$; the water extract was obtained with the lowest yield $(1.98 \%)$. Analyzing the content of secondary metabolites in all U. barbata dry extracts, it can be observed that UBEA had the highest amounts of usnic acid $(376.73 \mathrm{mg} / \mathrm{g})$ and tannins (24.40 mg PyE/g), and the lowest TPC (42.40 mg PyE/g). The dry acetone extract shows the highest polyphenol content $(101.09 \mathrm{mg} P y E / g)$ and a significant UAC 
(282.78 $\mathrm{mg} / \mathrm{g}$ ); tannins are found in UBA in a low concentration (3.85 $\mathrm{mg}$ PyE/g). The $U$. barbata dry extracts in ethanol and methanol displayed the secondary metabolites in similar amounts. The UBE has $127.21 \mathrm{mg} / \mathrm{g}$ UA and $67.3 \mathrm{mg}$ PyE/g polyphenols; in UBM, $\mathrm{UAC}=137.60 \mathrm{mg} / \mathrm{g}$ and TPC $=70.70 \mathrm{mg}$ PyE $/ \mathrm{g}$. Tannins were also quantified in both alcohol extracts as follows: $14.70 \mathrm{mg}$ PyE/g in UBE and $9.99 \mathrm{mg}$ PyE/g in UBM. Finally, the data summarized in Table 2 show that usnic acid was non-detected in the $U$. barbata water extract; UBW also has $45.80 \mathrm{mg}$ PyE/g polyphenols and the lowest TC (1.31 mg PyE/g).

\subsection{Antibacterial Activity}

As a significant secondary metabolite in Usnea barbata, responsible for various bioactivities, usnic acid was used as a positive control.

For each filter paper disc impregnated with $10 \mu \mathrm{L}$ of the sample solutions, the diffusible amounts of UA and various UBDE were calculated, and 1290-1620 $\mu \mathrm{g}$ is the range of these values, mentioned in Table 3. For selected antibiotics as positive controls, diffusible amounts were $5.0 \mu \mathrm{g}$ Levofloxacin (LEV) and $30 \mu \mathrm{g}$ Tetracycline (TET). The solvent for UA and UBDE (0.1\% DMSO), used as a negative control, showed no inhibitory effect on the bacterial strains' growth. Therefore, IZs values ( $\mathrm{mm}$ ) from Table 3 indicate the bioactivity of UBDE and UA exclusively. After $24 \mathrm{~h}$ incubation, UBW did not have any inhibitory action on Gram-positive nor Gram-negative bacterial growth (IZs $=0 \mathrm{~mm}$ ).

On Gram-positive bacteria, UA and all other UBDE (in ethyl acetate, acetone, ethanol, and methanol) variously inhibited the growth of bacterial colonies (Table 3).

Thus, on Staphylococcus aureus (S. aureus), IZs (mm) increased in order: $11.66 \pm 0.94 \mathrm{~mm}$ (UBE), $12.66 \pm 1.24 \mathrm{~mm}$ (UBA), $13.00 \pm 0.82 \mathrm{~mm}(\mathrm{UBM}), 14.33 \pm 0.94 \mathrm{~mm}$ (UBEA), and $16.00 \pm 0.82 \mathrm{~mm}$ (UA). Our results showed that $S$. aureus had intermediate susceptibility (directly proportional with the dose) to UA, compared to both antibiotics (IZs $>16 \mathrm{~mm}$ ), and resistance to all UBDE (IZs $\leq 14 \mathrm{~mm})$.

Enterococcus casseliflavus (E. casseliflavus) manifested the most significant susceptibility to UA and UBDE, compared with both antibiotics (IZs > $19 \mathrm{~mm}$, Table 3). The methanol extract had the highest antibacterial effect (IZs $=22.00 \pm 0.82 \mathrm{~mm})$, followed by all the other UBDE with similar IZs values (around $20 \mathrm{~mm}$ ).

On Streptococcus pyogenes (S. pyogenes), interpretation of the obtained data was performed in comparison with Levofloxacin. Our results show that $S$. pyogenes was susceptible only to UBM $(\mathrm{IZs}=20.00 \pm 1.63>17 \mathrm{~mm})$, and resistant to UA and other UBDE $(\mathrm{IZs} \leq 13 \mathrm{~mm})$.

Compared to the same antibiotic, Streptococcus pneumoniae (S. pneumoniae) proved to be susceptible to UA, UBEA, UBE, and UBA (IZs $\geq 17 \mathrm{~mm}$ ) and resistant to UBM (IZs $\leq 13 \mathrm{~mm}$ ). Both alcohol extracts (UBE and UBA) showed similar activities (IZs values were $18.00 \pm 1.63 \mathrm{~mm}$, and $18.00 \pm 0.82 \mathrm{~mm}$, respectively), being higher than UA $(17.00 \pm 1.63 \mathrm{~mm})$ and UBEA $(17.00 \pm 0.82 \mathrm{~mm})$.

The Gram-negative bacteria displayed very different levels of susceptibility after $24 \mathrm{~h}$ of incubation with UBDE (Table 3).

Therefore, Pseudomonas aeruginosa (P. aeruginosa) highlighted the most considerable level of susceptibility to UBE (IZs = 20.00 $\pm 1.63 \mathrm{~mm})$ and UBM $(\mathrm{IZs}=19.67 \pm 1.25 \mathrm{~mm})$, compared to both antibiotics (IZs $\geq 19 \mathrm{~mm}$ ). Compared only to Levofloxacin, $P$. aeruginosa was also susceptible to UBA $(17.00 \pm 0.82 \mathrm{~mm})$ and UBEA $(17.33 \pm 2.05 \mathrm{~mm})$ —with IZs $\geq 17 \mathrm{~mm}$ and intermediate susceptibility, dose-dependent, to UA (IZs = $16.00 \pm 0.82 \mathrm{~mm}$ ).

Escherichia coli (E. coli) was highly resistant to UA (IZs $=7.00 \pm 0.82<11 \mathrm{~mm}$ ) and all UBDE (IZs $=0 \mathrm{~mm})$. Finally, UBDE and UA did not show any inhibitory effects (IZs $=0 \mathrm{~mm})$ on Klebsiella pneumoniae (K. pneumoniae). 
Table 3. Antibacterial activity of Usnea barbata (L.) Weber ex F.H. Wigg dry extracts on Gram-positive and Gram-negative bacteria.

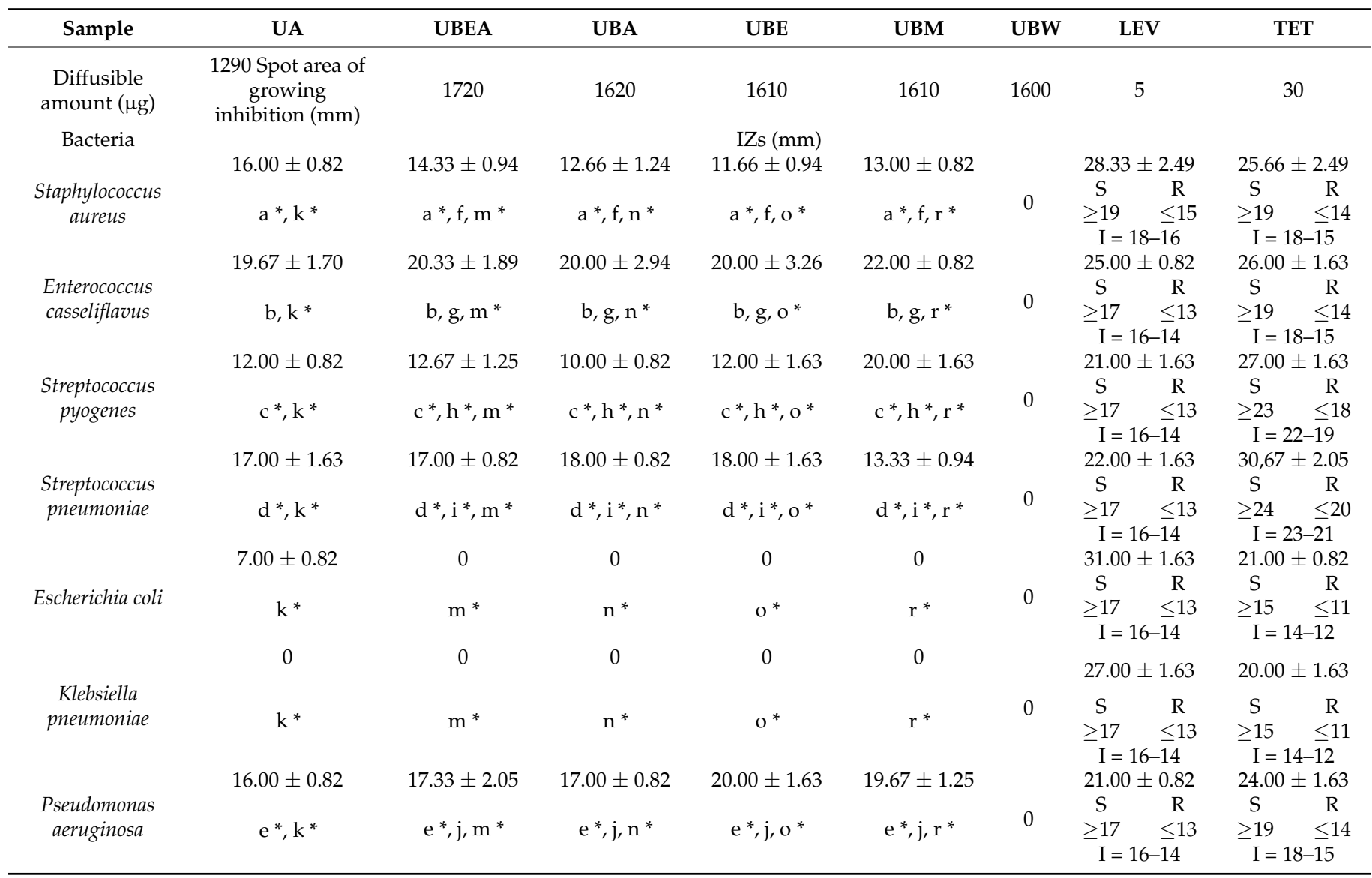

The analyses were performed in triplicate. The results are presented as mean $(\mathrm{n}=3) \pm$ standard deviation (SD). Levofloxacin and Tetracycline, with antibacterial effects against all bacterial species, were used for the interpretation of obtained results; their breakpoints $(\mathrm{mm})$ were indicated: S—susceptibility zone, R-resistance zone, and I-intermediate, dose-dependent zone. IZs — the size of inhibition zone diameter (mm), UA- usnic acid, UBEA-U. barbata dry extract in ethyl acetate, UBA-U. barbata dry extract in acetone, UBE-U. barbata dry extract in ethanol, UBM-U. barbata dry extract in methanol, UBW-U. barbata dry extract in water, LEV-Levofloxacin, TET-Tetracycline. Different lower-case letters ( $a, b, c, d, e, f, g, h, i, j, k, m, n, o$, and r) placed under IZs values show the series of IZs values compared for determination of $\mathrm{p}$-value; the symbol * indicates statistically significant differences $(p<0.05)$.

\subsection{Antifungal Activity}

Antifungal effects of UBDE were evaluated on two Candida species, Candida albicans (C. albicans) and Candida parapsilosis (C. parapsilosis) (Table 4). Two known antifungal drugs, Fluconazole (FLUCZ) $25 \mu \mathrm{g}$ and Voriconazole (VORI) $1 \mu \mathrm{g}$, were used as positive controls.

C. albicans displayed an intermediate susceptibility, dose-dependent, after $24 \mathrm{~h}$ of incubation with UBM $(16.33 \pm 2.05 \mathrm{~mm})$ and UBE $(15.33 \pm 1.24 \mathrm{~mm})$, compared to both antifungal agents (Table 4). UBA $(13.00 \pm 1.63 \mathrm{~mm})$ and UA $(10.00 \pm 0.82 \mathrm{~mm})$ also had inhibitory effects on C. albicans, but compared with Voriconazole $(\mathrm{I}=16-14)$, both IZs $\leq 13 \mathrm{~mm}$ were included in the resistance zone. Finally, C. albicans was also highly resistant to UBEA and UBW (IZs $=0 \mathrm{~mm}$ ).

Otherwise, C. parapsilosis showed significant susceptibility only to UA action $(20.00 \pm 1.63 \mathrm{~mm})$ compared to both antifungal drugs (IZs $\geq 19 \mathrm{~mm})$. It also had considerable resistance to all UBDE (Table 4). Hence, only UBEA showed low IZs $(7.00 \pm 0.82<13 \mathrm{~mm})$, and all other UBDE had no inhibitory effects (IZs $=0 \mathrm{~mm}$ ).

The influence of the metabolite content on antimicrobial activity was evaluated by performing linear trendlines with linear equations and comparing the correlation coefficient values $\left(R^{2}\right)$. The significant results $\left(R^{2}>0.5\right)$ are summarized in Table 5 . 
Table 4. Antifungal activity of Usnea barbata (L.) Weber ex F.H. Wigg dry extracts on Candida species.

\begin{tabular}{|c|c|c|c|c|c|c|c|c|}
\hline Sample & UA & UBEA & UBA & UBE & UBM & UBW & FLUCZ & VORI \\
\hline \multirow{3}{*}{$\begin{array}{c}\text { Diffusible } \\
\text { amount }(\mu \mathrm{g}) \\
\text { Fungi }\end{array}$} & 1290 & 1720 & 1620 & 1610 & 1610 & 1600 & 25 & 1 \\
\hline & \multicolumn{8}{|c|}{$\mathrm{IZs}(\mathrm{mm})$} \\
\hline & $10.00 \pm 0.82$ & 0 & $13.00 \pm 1.63$ & $15.33 \pm 1.24$ & $16.33 \pm 2.05$ & & $32.33 \pm 1.70$ & $34.33 \pm 1.25$ \\
\hline Candida albicans & $a^{*}, e^{*}$ & $a^{*}, c^{*}, f^{*}$ & $a^{*}, c^{*}, g^{*}$ & $a^{*}, c^{*}, h^{*}$ & $a^{*}, c^{*}, i^{*}$ & 0 & $\begin{array}{cc}\mathrm{S} & \mathrm{R} \\
\geq 19 & \leq 14 \\
\mathrm{I}=18-15\end{array}$ & $\begin{array}{cc}S & R \\
\geq 17 & \leq 13 \\
I=16-14\end{array}$ \\
\hline & $20.00 \pm 1.63$ & $7.00 \pm 0.82$ & 0 & 0 & 0 & & $25.67 \pm 2.49$ & $30.67 \pm 3.30$ \\
\hline $\begin{array}{c}\text { Candida } \\
\text { parapsilosis }\end{array}$ & $b^{*}, e^{*}$ & $b^{*}, d^{*}, f^{*}$ & $b^{*}, d^{*}, g^{*}$ & $b^{*}, d^{*}, h^{*}$ & $b^{*}, d^{*}, i^{*}$ & 0 & $\begin{array}{cc}S & R \\
\geq 19 & \leq 14 \\
I=18-15\end{array}$ & $\begin{array}{cc}S & R \\
\geq 17 & \leq 13 \\
I=16-14\end{array}$ \\
\hline
\end{tabular}

The analyses were performed in triplicate. The results are presented as mean $(\mathrm{n}=3) \pm$ standard deviation (SD). With well-established breakpoints for the tested fungal strains, Fluconazole and Voriconazole were used to interpret the data obtained; I = Intermediate susceptibility zone; S and R = Susceptibility and Resistance breakpoints. IZs — the size of inhibition zone diameter (mm), UA- usnic acid, UBEA-U. barbata dry extract in ethyl acetate, UBA-U. barbata dry extract in acetone, UBE-U. barbata dry extract in ethanol, UBM-U. barbata dry extract in methanol, UBW-U. barbata dry extract in water, FLUCZ-Fluconazole, VORI-Voriconazole. Different lower-case letters ( $a, b, c, d, e, f, g, h$, and i) indicate the IZs values compared for p-value determination; the symbol * shows statistically significant differences $(p<0.05)$.

Table 5. Correlation between the antimicrobial activity of various Usnea barbata (L.) Weber ex F.H. Wigg dry extracts and the metabolite content, displaying linear equations and correlation coefficient values.

\begin{tabular}{cccc}
\hline Bacteria & UAC & TPC & TC \\
\hline Staphylococcus aureus & $\mathrm{y}=0.0314 \mathrm{x}+4.53$ & - & - \\
Streptococcus & $\mathrm{R}=0.6187$ & - & - \\
pneumoniae & $\mathrm{R}^{2}=0.5571$ & - & - \\
Candida albicans & - & - & - \\
Candida parapsilosis & $\mathrm{y}=0.0156 \mathrm{x}-1.4826$ & $\mathrm{R}^{2}=0.5523$ & - \\
& $\mathrm{R}^{2}=0.5342$ & - & $\mathrm{y}=0.2796 \mathrm{x}-1.6342$ \\
\hline
\end{tabular}

UAC—usnic acid content, TPC—-total polyphenol content, TC—-tannin content, $\mathrm{R}^{2}$-correlation coefficient.

Thus, $U$. barbata dry extracts' antibacterial effects-expressed as IZs (mm) —against $S$. aureus and $S$. pneumoniae are moderately correlated with usnic acid content $\left(R^{2}=0.6187\right)$. UBDE inhibitory activity against $S$. pneumoniae also proved to have a moderate correlation with UAC $\left(\mathrm{R}^{2}=0.5571\right)$.

The data from Table 5 also show the correlation between antifungal activity of UBDE and secondary metabolite content. On C. albicans, the inhibitory effect moderately correlated with TPC $\left(\mathrm{R}^{2}=0.5523\right)$. On $C$. parapsilosis, the UBDE inhibitory effects were moderately correlated with the other two metabolites, UAC $\left(R^{2}=0.5342\right)$ and TC $\left(R^{2}=0.6766\right)$.

\section{Discussion}

Macroelements, such as $\mathrm{Ca}$ and $\mathrm{Mg}$, are highly represented in lichens [9,47], due to their role in photobiont metabolism. Other trace and heavy metals are contained in lichens in various amounts, depending on atmospheric and soil conditions [11,48,49]. Therefore, the elemental composition of $U$. barbata from the Călimani Mountains results from the habitat zone-specific properties. The Călimani Mountains are the highest Romanian volcanic mountains, and the coniferous forest soil is adjacent to the Tinovul Mare Poiana Stampei peat bog [43]. This peat bog has a natural origin, its accumulation beginning in the postglacial period; the soil color is tawny (brown) due to humic compounds and peat particles in suspension [43]. The particular conditions of the $U$. barbata native zone consist of seasonal water level fluctuations with thermic variations between $-1^{\circ} \mathrm{C}$ and $14^{\circ} \mathrm{C}, \mathrm{pH}$ values being 
3.6-5.0 [43]. The precipitation range in this zone is 600-800 $\mathrm{mL}$ [43]. Cazacu et al. (2018) explored this zone, extracting soil samples and performing $\mathrm{pH}$ measurement and trace metal analysis through $\mathrm{X}$-ray fluorescence spectrometry [43]. The data obtained showed $\mathrm{pH}$ values between 4.09 and 5.89 and several trace/heavy metals: $45.93 \mu \mathrm{g} / \mathrm{g} \mathrm{Cr}, 18.64 \mu \mathrm{g} / \mathrm{g} \mathrm{Co}$, $22.14 \mu \mathrm{g} / \mathrm{g} \mathrm{Ni}, 23.56 \mu \mathrm{g} / \mathrm{g} \mathrm{Cu}, 87.61 \mu \mathrm{g} / \mathrm{g} \mathrm{Zn}, 0.31 \mu \mathrm{g} / \mathrm{g} \mathrm{Cd}, 41.3 \mu \mathrm{g} / \mathrm{g} \mathrm{Pb}$, and $10.99 \mu \mathrm{g} / \mathrm{g}$ As [43]. Their amounts were higher than those mentioned in the national protocols, but no values exceeded the alert threshold [43]. Our elemental contents in dried $U$. barbata lichen were as follows: $1.002 \mu \mathrm{g} / \mathrm{g} \mathrm{Cr}, 0.449 \mu \mathrm{g} / \mathrm{g} \mathrm{Ni}, 1.523 \mu \mathrm{g} / \mathrm{g} \mathrm{Cu}, 20.536 \mu \mathrm{g} / \mathrm{g} \mathrm{Zn}$, and $1.296 \mu \mathrm{g} / \mathrm{g} \mathrm{Pb} ; \mathrm{Co}, \mathrm{Cd}$, and As were undetected because their contents were $<0.100 \mu \mathrm{g} / \mathrm{g}$. Both groups of trace/heavy metals values were correlated and presented in Figure 1.

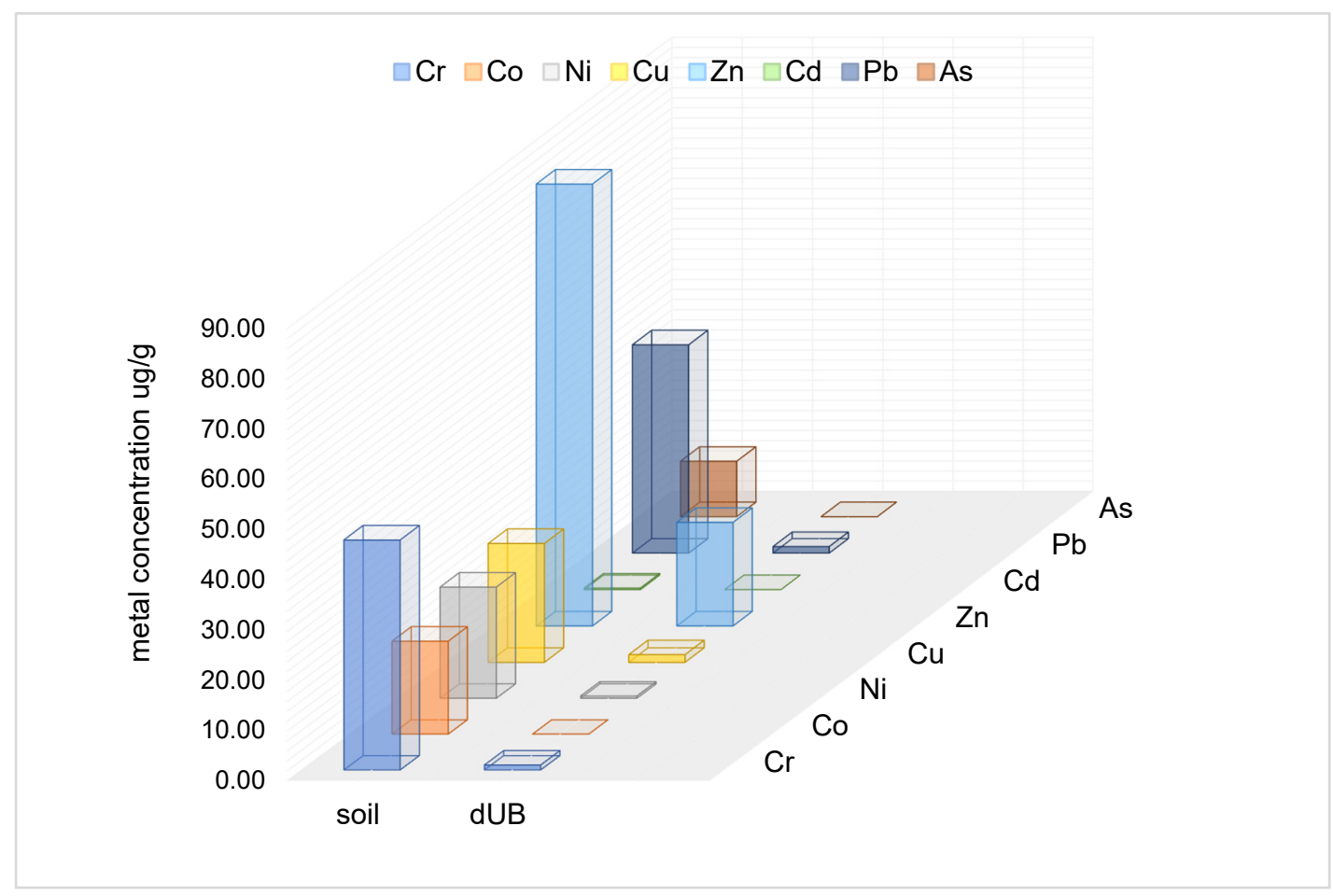

Figure 1. Correspondence between trace/heavy metal contents in soil and native dried Usnea barbata (L.) Weber ex F.H. Wigg (dUB).

Usnea barbata and other lichen species can be transplanted from native zones to polluted zones for biomonitoring reasons [50,51]. Several studies mentioned different Usnea sp. used in this scope and compared with other lichen species. Thus, Bergamaschi et al. (2007) proved that $U$. hirta transplanted to a city in northern Italy has the same ability as $H$. physodes and P. furfuracea to accumulate various metals [52].

According to Meli et al. (2018), lichens more easily accumulate air pollutants because they get most of their nutrients from the air; moreover, they have slow-growing properties and long life spans [53]. This capacity of lichens to accumulate various metals-especially heavy/trace metals-must be rigorously considered when exploring their use as edible or medicinal plants $[38,54]$. Heavy metal accumulation along the food chain represents a potential threat to human health [55], disturbing numerous biochemical processes [56]. Therefore, permissible limits of heavy/trace metals in edible and medicinal plants were established, aiming for their safe use [55]. The World Health Organization (WHO, 1996) and the Food and Agriculture Organization of the United Nations (FAO) indicated the permissible limits for heavy metals in edible plants as follows: $0.5 \mu \mathrm{g} / \mathrm{g}$ arsenic (As), $0.02 \mu \mathrm{g} / \mathrm{g}$ cadmium (Cd), $1.3 \mu \mathrm{g} / \mathrm{g}$ chromium $(\mathrm{Cr}), 0.01 \mu \mathrm{g} / \mathrm{g}$ cobalt $(\mathrm{Co}), 10 \mu \mathrm{g} / \mathrm{g}$ copper $(\mathrm{Cu}), 0.03 \mu \mathrm{g} / \mathrm{g}$ mercury $(\mathrm{Hg}), 0.1 \mu \mathrm{g} / \mathrm{g}$ nickel $(\mathrm{Ni}), 2 \mu \mathrm{g} / \mathrm{g}$ lead $(\mathrm{Pb}), 0.03 \mu \mathrm{g} / \mathrm{g}$ vanadium (V), and $50 \mu \mathrm{g} / \mathrm{g}$ zinc (Zn) [57,58]. 
Simkova and Polesny (2015) mentioned $U$. barbata as a culinary plant in the Balkan zone, consumed as mush and ingredients of bread [59]. Our metal content values, correlated to the previously mentioned limits, show that $\mathrm{Cr}(1.002 \pm 0.008 \mu \mathrm{g} / \mathrm{g}), \mathrm{Cu}(1.523 \pm 0.013 \mu \mathrm{g} / \mathrm{g})$, $\mathrm{Pb}(1.296 \pm 0.007 \mu \mathrm{g} / \mathrm{g})$, and $\mathrm{Zn}(20.536 \pm 0.125 \mu \mathrm{g} / \mathrm{g})$ are lower than corresponding permissible limit values. Other heavy metals registered higher contents than permissible ones: $\mathrm{Hg}(0.671 \pm 0.020 \mu \mathrm{g} / \mathrm{g}), \mathrm{Ni}(0.449 \pm 0.011 \mu \mathrm{g} / \mathrm{g})$, and V $(0.241 \pm 0.004 \mu \mathrm{g} / \mathrm{g})$. The other toxic metals (As, Cd, and $\mathrm{Co}$ ) were non-detected.

Dobrescu et al. (1993) displayed various $U$. barbata therapeutical properties, mentioning that it is used in traditional medicine as an antiseptic (in the USA and Spain) and for ameliorating the symptoms associated with various diseases: insomnia, bleeding, nausea, jaundice, and whooping cough (in Europe) [60]. The permissible limits for heavy/trace metals in medicinal plants are higher than in edible ones. According to the European Pharmacopoeia [55], the following permissible limits are available: $1 \mu \mathrm{g} / \mathrm{g} \mathrm{Cd}, 2 \mu \mathrm{g} / \mathrm{g}$ $\mathrm{Cr}, 0.1 \mu \mathrm{g} / \mathrm{g} \mathrm{Hg}$, and $5 \mu \mathrm{g} / \mathrm{g} \mathrm{Pb}$. The Pharmacopoeia of the People's Republic of China recommends $2 \mu \mathrm{g} / \mathrm{g}$ As, $0.3 \mu \mathrm{g} / \mathrm{g} \mathrm{Cd}, 20 \mu \mathrm{g} / \mathrm{g} \mathrm{Cu}$, and $0.2 \mu \mathrm{g} / \mathrm{g} \mathrm{Hg}$ [61]. According to the admissible limits of the WHO (2012) and the US Food and Drugs Administration (FDA), the following values were established: $10 \mu \mathrm{g} / \mathrm{g} \mathrm{As}, 0.2 \mu \mathrm{g} / \mathrm{g} \mathrm{Cd}, 20 \mu \mathrm{g} / \mathrm{g} \mathrm{Cu}$, $1 \mu \mathrm{g} / \mathrm{g} \mathrm{Hg}, 10 \mu \mathrm{g} / \mathrm{g} \mathrm{Pb}$, and $50 \mu \mathrm{g} / \mathrm{g}$ Zn [61]. Our results showed that autochthonous $U$. barbata contained all heavy/trace metal contents in lower amounts than these permissible limits. However, the mercury content $(0.671 \pm 0.020 \mu \mathrm{g} / \mathrm{g})$ was lower than the WHO's and the FDA's permissible limits $(1 \mu \mathrm{g} / \mathrm{g})$, but was over the ones mentioned in the European Pharmacopoeia $(0.1 \mu \mathrm{g} / \mathrm{g})$ and the Pharmacopoeia of the People's Republic of China $(0.2 \mu \mathrm{g} / \mathrm{g})$.

The secondary metabolites display significant roles in lichens' metal tolerance. These compounds are in vitro chelators of cations, including heavy metals. Bačkor and Fahselt (2004) [4] found that usnic acid may be associated with $\mathrm{Cu}, \mathrm{Ni}, \mathrm{Fe}$, and $\mathrm{Al}$ in Cladonia pleurota. Another team of researchers found that usnic acid does not protect the cells of the photobiont Trebouxia erici against the toxic effect of $\mathrm{Cu}$ in a culture medium; both usnic acid and $\mathrm{Cu}$ became phytotoxic and inhibited photobiont growth, viability, and chlorophyll fluorescence [62]. Although metal complexes with secondary metabolites of lichens have been reported several times, their impacts on metabolic processes is far from wholly clarified [63].

Lichen secondary metabolites are also known for their antimicrobial activities. Antonenko et al. (2019) [64] described usnic acid as calcium ionophore [65] and protonophore, deciphering its antimicrobial mechanism. They highlighted the essential role of all $\mathrm{OH}$ groups of UA in protonophore potential [64], proving their abilities to induce membrane potential dissipation in isolated liver mitochondria and bacterial cells [65].

Polyphenols can generate aggregates in the cell wall of Gram-positive bacteria. They can also induce microscale grooves in the Gram-negative bacterial cell envelopes [66,67]. Moreover, in disturbing the folate metabolism, various polyphenols could inhibit ergosterol production in their action against Candida sp. [68]. In our previous study, using the HPLC method, we identified six phenolic acids (caffeic acid, p-coumaric acid, ellagic acid, chlorogenic acid, gallic acid, and cinnamic acid) in U. barbata ethanol extract. Chlorogenic acid, gallic acid, and p-coumaric acid were also found in $U$. barbata water extract [37].

As macromolecular polyphenols, tannins contain many phenolic hydroxylic groups, and this structural feature underlies their antimicrobial action [69] by various mechanisms. Tannins can interact with bacterial cell membranes to mediate antibacterial effects by affecting the membrane potential or increasing permeability [70]. They also can inhibit bacterial cell wall synthesis by directly binding to it or inactivating the enzymes. Furthermore, tannins seem to affect bacterial growth in several ways, such as inhibition of extracellular microbial enzymes, direct action on microbial metabolism through inhibition of oxidative phosphorylation, or deprivation of the substrates required for microbial growth [70]. For example, the o-dihydroxy phenyl groups in tannin molecules are involved in the chelation 
of ferric ions [71]; therefore, iron cannot be available to bacteria, leading to the inhibition of bacterial growth due to iron deprivation.

The antimicrobial effects of various secondary lichen metabolites could explain the antibacterial and antifungal activities of Usnea barbata extracts. Our data showed that $S$. aureus was susceptible to UA in a dose-dependent manner and resistant to all UBDE; on the other hand, E. casseliflavus was highly susceptible to UA and all UBDE. On S. pyogenes, only UBM had an antibacterial effect; this bacterium was resistant to UA and other UBDE. Usnic acid, UBEA, UBE, and UBA manifested antibacterial action against S. pneumoniae; only UBM was ineffective. On P. aeruginosa, all UBDE were significantly active, and UA proved to have an antibacterial effect in a dose-dependent manner. Contrariwise, the other Gram-negative bacteria, E. coli and K. pneumoniae, were highly resistant to UA and all UBDE. Finally, C. albicans was susceptible in a dose-dependent manner to UBM and UBE, and C. parapsillosis showed a significant susceptibility to UA and a high resistance to all UBDE.

These results can be correlated with $U$. barbata's phytochemical and mineral profile, and explained based on the various metabolites with antibacterial and antifungal activity quantified in each UBDE. Thus, the solubility of usnic acid increases in order: water, ethanol, methanol, acetone, and ethyl acetate [72]; usnic acid and UBEA showed similar antibacterial activities in our study because this lichen extract has the highest usnic acid content [46]. On Candida sp., we can observe that, when only usnic acid had considerable inhibitory activity, UBDE in ethyl acetate showed an insignificant effect; also, when usnic acid showed a low inhibition, UBEA presented no activity. UBDE in methanol, acetone, and ethanol contain different secondary metabolites with antimicrobial activity (usnic acid polyphenols and tannins); thus, their approximately similar antibacterial and antifungal effects, with low differences, can be explained. The various mechanisms involved in both activities can also justify the differences between antibacterial and antifungal effects. Water extract had only low polyphenol and tannin contents; thus, the fact that UBW did not show any inhibitory action on bacterial or fungal colony growth could be justified.

These data suggest the involvement of all metabolites in the antimicrobial activities of $U$. barbata extracts. Moreover, these effects may be due to the quantified metals in the dried lichen ( $\mathrm{Zn} \mathrm{[73],} \mathrm{Cu}$ [74], and Fe [75]), which could also be found in UBDE. These metals could have their own activities or generate synergisms, potentiating other constituents antibacterial and antifungal effects.

Numerous authors have evaluated lichen extracts' antibacterial and antifungal activities on various pathogens resistant to current antimicrobial medications; their results were similar to those obtained in this study.

For example, Shrestha et al. (2014) studied the antibacterial activity of 34 North American lichen species against $S$. aureus, P. aeruginosa, and E. coli [76]. While all lichen species tested showed antibacterial action on S. aureus and P. aeruginosa, E. coli was susceptible to only three species out of the 34 studied; only two tested Usnea species had no antibacterial activity on E. coli. Usnea hirta and Usnea strigosa, tested in this study, showed high antibacterial activity only against $S$. aureus and P. aeruginosa.

In another study, Jha et al. (2017) analyzed S. aureus, K. pneumoniae, and C. albicans susceptibility to the inhibitory actions of 84 lichen species from Nepal. Their results proved that seventeen extracts showed activities against $S$. aureus and 45 extracts against $K$. pneumoniae; twelve extracts showed inhibitory activities against both bacterial species [77]. Only three specimen extracts were active against $C$. albicans. The three tested Usnea species (Usnea pectinata, Usnea bailey, and Usnea coraline) showed no antimicrobial activity in their study.

Kumar et al. (2017) extracted protolichesterinic acid from Usnea albopunctata and studied its antifungal effect against four Candida species, including C. albicans and C. parapsilosis; the diameters of inhibition zones were $21 \mathrm{~mm}$ and $22 \mathrm{~mm}$, respectively [78]. Our results also showed that the antifungal activity of usnic acid was higher against $C$. parapsilosis $(20 \mathrm{~mm})$ than against $C$. albicans $(10 \mathrm{~mm})$. 
Rankovic et al. (2009) studied the antibacterial action of five lichen species, testing three different extracts for each lichen species: acetone, methanol, and water [79]. All lichen extracts in water showed no antibacterial activity; both extracts in methanol and acetone registered a high level of inhibition on bacterial strains. Singha et al. (2011), using the previously mentioned solvents for lichen extraction, reported that methanol extracts had the most intense antibacterial effects [80].

Analyzing the antimicrobial activity of lichen extracts, most studies were performed by testing 1-3 extracts of the same species in different solvents [81]. Other researchers compared the actions of lichens extracts using 1-3 solvents with those of the most active metabolites [82] contained by the tested species [83]. However, studies that evaluate more than three extracts in different solvents of the same lichen species [84] are in a much smaller number [85]; our study examined five Usnea barbata (L.) F.H. Wigg dry extracts, and the differences between their antimicrobial activities were analyzed in relationship with the phytoconstituents extracted with each solvent.

\section{Materials and Methods}

\subsection{Lichen Samples}

$U$. barbata thalli were harvested one by one from the branches of conifers in the Călimani Mountains - the highest Romanian volcanic mountains-in the early spring of 2020. The freshly collected lichens were separated from the impurities; then, they were dried at $18-25{ }^{\circ} \mathrm{C}$ in a herbal room, harbored from sunlight. Preservation of the dried lichens for an extended period was performed under the same conditions. The Department of Pharmaceutical Botany of the Faculty of Pharmacy, Ovidius University of Constanta accomplished the $U$. barbata identification using standard methods [86].

\subsection{Elemental Analysis}

The dried $U$. barbata lichen was used for ICP-MS elemental analysis, according to the European Pharmacopoeia 10.0 [87]; 23 elements were analyzed: $\mathrm{Ca}, \mathrm{Fe}, \mathrm{Mg}, \mathrm{Mn}, \mathrm{Zn}, \mathrm{Al}$, $\mathrm{Ag}, \mathrm{Ba}, \mathrm{Co}, \mathrm{Cr}, \mathrm{Cu}, \mathrm{Li}, \mathrm{Ni}, \mathrm{Tl}, \mathrm{V}, \mathrm{Mo}, \mathrm{Pd}, \mathrm{Pt}, \mathrm{Sb}, \mathrm{As}, \mathrm{Pb}, \mathrm{Cd}$, and $\mathrm{Hg}$, using the ICP ability to generate charged ions from the element species within the lichen sample [87]. Thus, they are guided [88] into a mass spectrometer and separated according to their mass-to-charge ratio $(m / z)$ [87].

\subsubsection{Equipment}

The quadrupole inductively coupled plasma mass spectrometer was a NexION ${ }^{\mathrm{TM}}$ $300 S$ (PerkinElmer, Inc., Hopkinton, MA, USA), with a triple cone interface and a fourstage vacuum system. This ICP-MS system is equipped with a universal cell with two gas lines (helium, ammonia, and methane) that allows operation in collision mode (helium) and reaction mode (ammonia/methane). The ICP-MS is equipped with a recirculating chiller (PerkinElmer, Shelton) and a peristaltic pumping system with acid-resistant tubing $-0.38 \mathrm{~mm}$ interior diameter (id) tubing for sample introduction and $1.3 \mathrm{~mm}$ id for drain exclusive.

The samples were digested in mineralization vessels using Rotor 16HF100 in a PROSOLV microwave digestion system (Anton Paar GmbH, Graz, Austria) using a pressureactivated venting concept. The Directed Multimode Cavity (DMC) enables highly efficient turbo heating with one magnetron in a compact system combined with a turbo cooling system for rapid cooling from $180^{\circ} \mathrm{C}$ to $70^{\circ} \mathrm{C}$.

\subsubsection{Dried Lichen Mineralization}

A sample of $0.250 \mathrm{~g} \pm 0.05 \mathrm{~g}$ homogenized dried lichen was weighed on an analytical balance Quintix ${ }^{\circledR}$ 224-1CEU (Sartorius Lab Instruments GmbH \& Co. KG, Göttingen, Germany). Then, it was added to the digestion vessel with $4 \mathrm{~mL} 65 \% \mathrm{HNO}_{3}$ and $1 \mathrm{~mL} \mathrm{30 \%}$ $\mathrm{H}_{2} \mathrm{O}_{2}$ (Merck, KGaA, Darmstadt, Germany). After 30 min pre-reaction, the dishes were 
placed in the microwave digestion system. The selected parameters of the digestion process are registered in Table 6.

Table 6. Dried lichen digestion conditions.

\begin{tabular}{ccccc}
\hline Step & $\begin{array}{c}\text { Temperature } \\
\left({ }^{\circ} \mathbf{C}\right)\end{array}$ & $\begin{array}{c}\text { Power of Microwave } \\
\text { Digestion System } \mathbf{( W )}\end{array}$ & $\begin{array}{c}\text { Time } \\
(\mathbf{m i n})\end{array}$ & $\begin{array}{c}\text { Fan } \\
\text { Level }\end{array}$ \\
\hline Power ramp & - & 1450 & 15 & 1 \\
Power hold & 180 & 1450 & 45 & 1 \\
Cooling & 70 & 0 & - & 3 \\
\hline
\end{tabular}

The reagent control (blank) was obtained by adding $4 \mathrm{~mL} 65 \% \mathrm{HNO}_{3}$ and $1 \mathrm{~mL} \mathrm{30 \%}$ $\mathrm{H}_{2} \mathrm{O}_{2}$ in a sample-free Teflon tube and mineralizing it with the dried lichen. After the digestion program, the samples were transferred to $25 \mathrm{~mL}$ volumetric flasks and brought to the mark with ultrapure deionized water. The ultrapure water was obtained with a Simplicity ${ }^{\circledR}$ UV Water Purification System (Merck Millipore, Burlington, MA, USA), equipped with a dual-wavelength UV lamp ensuring photo-oxidation of organic compounds and flow rates $>0.5 \mathrm{~L} / \mathrm{min}$.

\subsubsection{Standard Solutions}

Two different concentrations of standard elemental stock solutions (PerkinElmer, Inc, Hopkinton, MA, USA) were used. The mercury stock solution had a concentration of $10 \mu \mathrm{g} / \mathrm{mL}$, and all other elements' stock solutions' concentrations were $1000 \mu \mathrm{g} / \mathrm{mL}$. The Multi-Element Standard for ICP-MS Instrument Calibration was requested for NexION Setup Solution (Be, Ce, Fe, In, $\mathrm{Li}, \mathrm{Mg}, \mathrm{Pb}, \mathrm{U}$ ) and for NexION KED Mode Setup Solution (Be, $\mathrm{Ce}, \mathrm{Fe}, \mathrm{In}, \mathrm{Li}, \mathrm{Mg}, \mathrm{Pb}, \mathrm{U})$. The preparation of the standard solutions and calibration standard solutions is detailed in the Supplementary Material. For each element calibration curve, different calibration standard solutions E1-E5 (Tables S2-S4, Supplementary Material) with several concentrations $(\mu \mathrm{g} / \mathrm{L})$ were obtained (Table 7$)$.

Table 7. Concentrations $(\mu \mathrm{g} / \mathrm{L})$ of calibration standard solutions E1-E5 for different elements.

\begin{tabular}{cccccc}
\hline Element & E1 $(\mu \mathrm{g} / \mathrm{L})$ & E2 $(\mu \mathrm{g} / \mathrm{L})$ & E3 $(\mu \mathrm{g} / \mathrm{L})$ & E4 $(\mu \mathrm{g} / \mathrm{L})$ & E5 $(\mu \mathrm{g} / \mathrm{L})$ \\
\hline $\mathrm{As}, \mathrm{Pb}, \mathrm{Cd}, \mathrm{Hg}$ & 1 & 5 & 10 & 15 & 25 \\
$\mathrm{Ca}, \mathrm{Fe}, \mathrm{Mg}, \mathrm{Mn}, \mathrm{Zn}$ & 50 & 100 & 200 & 300 & 500 \\
$\mathrm{Al}$ & 10 & 50 & 100 & 150 & 200 \\
$\mathrm{Ag}, \mathrm{Ba}, \mathrm{Co}, \mathrm{Cr}, \mathrm{Cu}, \mathrm{Li}$, & 1 & 5 & 10 & 50 & 100 \\
$\mathrm{Ni}, \mathrm{Tl}, \mathrm{V}, \mathrm{Mo}, \mathrm{Pd}, \mathrm{P}, \mathrm{Sb}$ & & & & & \\
\hline
\end{tabular}

\subsubsection{Working Conditions}

The ICP-MS elemental analysis was performed by the kinetic energy discrimination (KED) method, measuring unit = counts per second (CPS). The peristaltic pumping system was washed with each sample (35 s), followed by a read delay (15 s), and the analytical phase. Afterwards, the peristaltic pump was washed with ultrapure deionized water (45 s). All processes involved an operation speed $=20-24$ rotations $/$ minute $(\mathrm{rpm})$.

\subsubsection{Specificity}

Specificity was verified by determining the recovery of each analyzed element in spiked sample solutions. Sample spiking was performed at each element's estimated LOQ $(\mu \mathrm{g} / \mathrm{L})$ value. According to the United States Environmental Protection Agency (USEPA), available spike recovery (\%) values are included in the range 70-150\% [89]. Spike recovery (\%) was calculated according to the following Equation (1):

$$
\text { Spike recovery }(\%)=\frac{\text { concentration of spiked solution-concentration of sample solution }}{\text { theoretical concentration of spiked solution }} \times 100
$$




\subsubsection{Spike Solutions}

The four spike solutions were prepared using standard elemental stock solutions (Supplementary Material), as follows:

Spike Sol. I (As, Pb, Cd, and $\mathrm{Hg}) 1 \mathrm{mg} / \mathrm{L}$ : Into a $20 \mathrm{~mL}$ volumetric flask were added: $0.2 \mathrm{~mL} \mathrm{65 \%} \mathrm{HNO}_{3}, 0.02 \mathrm{~mL}$ solution As $1000 \mathrm{mg} / \mathrm{L}, 0.02 \mathrm{~mL}$ solution $\mathrm{Pb} 1000 \mathrm{mg} / \mathrm{L}$, $0.02 \mathrm{~mL}$ solution $\mathrm{Cd} 1000 \mathrm{mg} / \mathrm{L}$, and $2 \mathrm{~mL}$ solution $\mathrm{Hg} 10 \mathrm{mg} / \mathrm{L}$; then, the obtained solution was brought to the mark with ultrapure water;

Spike Sol. II (Ca, $\mathrm{Fe}, \mathrm{Mg}, \mathrm{Mn}$, and $\mathrm{Zn}) 10 \mathrm{mg} / \mathrm{L}$ : Into a $50 \mathrm{~mL}$ volumetric flask were added: $0.5 \mathrm{~mL} 65 \% \mathrm{HNO}_{3}, 0.5 \mathrm{~mL}$ solution Ca $1000 \mathrm{mg} / \mathrm{L}, 0.5 \mathrm{~mL}$ solution Fe $1000 \mathrm{mg} / \mathrm{L}$, $0.5 \mathrm{~mL}$ solution $\mathrm{Mg} 1000 \mathrm{mg} / \mathrm{L}, 0.5 \mathrm{~mL}$ solution $\mathrm{Mn} 1000 \mathrm{mg} / \mathrm{L}$, and $0.5 \mathrm{~mL}$ solution $\mathrm{Zn}$ $1000 \mathrm{mg} / \mathrm{L}$; then, the flask content was brought to the mark with ultrapure water;

Spike Sol. III (Al) $10 \mathrm{mg} / \mathrm{L}$ : Into a $50 \mathrm{~mL}$ volumetric flask were added $0.5 \mathrm{~mL} 65 \%$ HNO3, $0.5 \mathrm{~mL}$ solution $\mathrm{Al} 1000 \mathrm{mg} / \mathrm{L}$, and ultrapure water up to the mark;

Spike Sol. IV (Ag, Ba, Co, Cr, Cu, Li, Ni, Tl, V, Mo, Pd, Pt, and Sb) $1 \mathrm{mg} / \mathrm{L}$ : Into a $50 \mathrm{~mL}$ volumetric flask were added: $0.5 \mathrm{~mL} \mathrm{65 \%} \mathrm{HNO}_{3}, 0.05 \mathrm{~mL}$ solution $\mathrm{Ag} 1000 \mathrm{mg} / \mathrm{L}$, $0.05 \mathrm{~mL}$ solution Ba $1000 \mathrm{mg} / \mathrm{L}, 0.05 \mathrm{~mL}$ solution Co $1000 \mathrm{mg} / \mathrm{L}, 0.05 \mathrm{~mL}$ solution $\mathrm{Cr}$ $1000 \mathrm{mg} / \mathrm{L}, 0.05 \mathrm{~mL}$ solution $\mathrm{Cu} 1000 \mathrm{mg} / \mathrm{L}, 0.05 \mathrm{~mL}$ solution Li $1000 \mathrm{mg} / \mathrm{L}, 0.05 \mathrm{~mL}$ solution Ni $1000 \mathrm{mg} / \mathrm{L}, 0.05 \mathrm{~mL}$ solution Tl $1000 \mathrm{mg} / \mathrm{L}, 0.05 \mathrm{~mL}$ solution V $1000 \mathrm{mg} / \mathrm{L}$, $0.05 \mathrm{~mL}$ solution Mo $1000 \mathrm{mg} / \mathrm{L}, 0.05 \mathrm{~mL}$ solution Pd $1000 \mathrm{mg} / \mathrm{L}, 0.05 \mathrm{~mL}$ solution Pt $1000 \mathrm{mg} / \mathrm{L}$, and $0.05 \mathrm{~mL}$ solution Sb $1000 \mathrm{mg} / \mathrm{L}$; then, the obtained solution was brought to the mark with ultrapure water.

\subsubsection{Spiked Solutions}

Spiked solutions at LOQ $(\mu \mathrm{g} / \mathrm{L})$ estimated level of each element were prepared as follows: a sample of $0.250 \mathrm{~g} \pm 0.05 \mathrm{~g}$ homogenized dried lichen was weighed on a Quintix ${ }^{\circledR}$ 433 analytical balance 224-1CEU (Sartorius Lab Instruments GmbH \& Co. KG, Göttingen, Germany). Then, it was added to the digestion vessel with $4 \mathrm{~mL} 65 \% \mathrm{HNO}_{3}$ and $1 \mathrm{~mL} \mathrm{30 \%}$ $\mathrm{H}_{2} \mathrm{O}_{2}$ (Merck, Germany). Supplementarily, in the Teflon vessel, 0.025 or $0.125 \mathrm{~mL}$ spike solutions were added according to the data summarized in Table 8. After the digestion program, the samples were transferred to $25 \mathrm{~mL}$ volumetric flasks and brought to the mark with ultrapure deionized water.

Table 8. Preparation of spiked solutions.

\begin{tabular}{|c|c|c|c|}
\hline \multirow{2}{*}{$\begin{array}{c}\text { Element } \\
\text { (Spike) }\end{array}$} & \multicolumn{2}{|c|}{ Spike Solution } & \multirow{2}{*}{$\begin{array}{c}\text { Spiked Solution } \\
\text { Theoretical } \\
\text { Concentration }(\mu \mathrm{g} / \mathrm{L}\end{array}$} \\
\hline & $\begin{array}{l}\text { Concentration } \\
(\mathrm{mg} / \mathrm{L})\end{array}$ & Volume (mL) & \\
\hline $\mathrm{As}, \mathrm{Pb}, \mathrm{Cd}, \mathrm{Hg}$ & 1 & 0.025 & 1 \\
\hline $\mathrm{Ca}, \mathrm{Fe}, \mathrm{Mg}, \mathrm{Mn}, \mathrm{Zn}$ & 10 & 0.125 & 50 \\
\hline $\mathrm{Al}$ & 10 & 0.025 & 10 \\
\hline $\begin{array}{c}\mathrm{Ag}, \mathrm{Ba}, \mathrm{Co}, \mathrm{Cr}, \mathrm{Cu}, \mathrm{Li}, \mathrm{Ni}, \\
\mathrm{Tl}, \mathrm{V}, \mathrm{Mo}, \mathrm{Pd}, \mathrm{Pt}, \mathrm{Sb}\end{array}$ & 1 & 0.025 & 1 \\
\hline
\end{tabular}

In the spike recovery (\%) calculation, we prepared two dilutions of the sample solution-1:10 $(\mathrm{d}=10)$ and 1:100 $(\mathrm{d}=100)$ - using $2.5 \mathrm{~mL}$ and $0.25 \mathrm{~mL}$, respectively, of the mineralized sample solution. These were added into two $25 \mathrm{~mL}$ volumetric flasks. Then, the corresponding spike solutions from Table 8 were added and brought to the mark with ultrapure deionized water. All of these data are presented in Table S1, Supplementary Material. 


\subsubsection{Calibration Curves}

The calibration curves were performed using five calibration standard solutions (E1E5, $\mu \mathrm{g} / \mathrm{L}$ ) for each element (Table S2 and Figure S1, Supplementary Material). Using linear equations, the correlation coefficients $\left(\mathrm{R}^{2}\right)$ were determined, with the admissibility condition requesting an $R^{2}$ value $>0.99$.

\subsubsection{Detection Limits and Quantification Limits}

The detection limit (LOD) and quantification limit (LOQ) values for each element were calculated using the standard deviation (SD) for ten determinations of the first calibration standard solution E1 and the slope of the calibration curve (Tables S2-S5, Supplementary Material), applying the following Equation (2):

$$
\mathrm{LOD}=3.3 \times \mathrm{SD} / \text { Slope }
$$

The element content (Table 1), expressed as $\mu \mathrm{g} / \mathrm{g}$ or $\mathrm{mg} / \mathrm{kg}$, was calculated according to the data from the calibration curve: element concentration $(\mu \mathrm{g} / \mathrm{L})$, the weighted sample amount $-m(\mathrm{~g})$, and the final volume of the sample solution $-V_{f}(\mathrm{~mL})$, according to Equation (3):

$$
\text { Element content }(\mu \mathrm{g} / \mathrm{g})=\frac{\text { element concentration }\left(\frac{\mu \mathrm{g}}{\mathrm{L}}\right) \times V_{f}(\mathrm{~mL})}{m(\mathrm{~g}) * 1000}
$$

\subsubsection{Data Analysis, Software}

Data obtained were processed with Syngistix software (PerkinElmer, Inc., Hopkinton, MA, USA) Version 2.3. for ICP-MS. Elemental analysis was performed in triplicate, and the results are expressed as mean $(n=3) \pm S D$.

\subsection{U. barbata Dry Extracts-Preparation}

In a Soxhlet continuous reflux system, the dried lichen was ground into a powder; $20 \mathrm{~g}$ of dried lichen was extracted for $8 \mathrm{~h}$ with $150 \mathrm{~mL}$ solvent: ethyl acetate, methanol (Chemical Company, Iasi, Romania), acetone, ethanol (Chimreactiv S.R.L., Bucharest, Romania), and water [46]. The extraction temperature was different for each extract, being around the boiling point of each solvent (Table 1). After filtration with filter paper, UBW was concentrated on a Rotavapor R-215 with a vacuum controller V-850 (BÜCHI Labortechnik AG, Flawil, Switzerland), and lyophilized with a freeze-dryer Christ Alpha 1-2L (Martin Christ Gefriertrocknungsanlagen GmbH, Osterode am Harz, Germany) connected to a vacuum pump RZ 2.5 (VACUUBRAND GmbH, Wertheim, Germany) [46]. For UBEA, UBA, UBE, and UBM, the rotary evaporator TurboVap 500 (Caliper Life Sciences Inc, Hopkinton, MA, USA) evaporated the correspondent solvents [41]. Next, each extract was kept for $16 \mathrm{~h}$ in a chemical exhaust hood for optimal solvent evaporation. All obtained $U$. barbata dry extracts were transferred to sealed-glass containers and stored in the freezer (Sirge ${ }^{\circledR}$ Elettrodomestici-S.A.C. Rappresentanze, Torino, Avigliana (TO) Italy) at $-24{ }^{\circ} \mathrm{C}$ until processing [46].

\subsection{Determination of the Usnic Acid Content}

Usnic acid was determined in $U$. barbata dry extracts by ultra-high performance liquid chromatography (UHPLC) [46]. All UBDE were re-dissolved in acetone, ethyl acetate, ethanol, methanol, and water, and diluted to 1:50 with DMSO [46]. The PerkinElmer ${ }^{\circledR}$ Flexar ${ }^{\circledR}$ FX-15 UHPLC system fitted with a Flexar FX PDA-Plus photodiode array detector was the platform for this analysis. The Brownlee Analytical C18 column, with an inner diameter of $4.6 \mathrm{~mm}$ and a length of $150 \mathrm{~mm}$, was filled with $5 \mu \mathrm{m}$ superficially porous particles. Working conditions consisted of: flow $=1.5 \mathrm{~mL} / \mathrm{min}$; temperature in the column compartment $=25{ }^{\circ} \mathrm{C}$; injection volume $=20 \mu \mathrm{L}$; and analysis time: $10 \mathrm{~min}$. The mobile 
phase was an isocratic system of methanol/water/glacial acetic acid (80:15:5). After elution from the column, the separated compounds were analyzed at a wavelength of $282 \mathrm{~nm}$ [46].

\subsection{Determination of the Total Polyphenol Content}

The total polyphenol content was determined with Folin-Ciocâlteu reagent (phosphomolybdotungstic acid) using pyrogallol as the standard [46]. The method was described in our previous study [46] and TPC values were expressed as mg of pyrogallol equivalents (PyE) per $\mathrm{g}$ UBDE. For this analysis, $5 \mathrm{~mL}$ of each UBDE (A1-A5) filtered through 99 filter paper were added to five volumetric flasks of $25 \mathrm{~mL}$ and completed up to the sign with the same solvent. Then, $2 \mathrm{~mL}$ of each previously obtained solution (B1-B5) were added into five volumetric flasks of $25 \mathrm{~mL}$, with $1 \mathrm{~mL}$ of Folin-Ciocâlteu reagent, $10 \mathrm{~mL}$ water, and $290 \mathrm{~g} / \mathrm{L}$ of $\mathrm{Na}_{2} \mathrm{CO}_{3}$ solution, up to the mark. After $30 \mathrm{~min}$ of reaction at room temperature, the absorbance values (each value was noted with A1 in the calculation formula) were determined at $760 \mathrm{~nm}$, using a Jasco V630 UV-Vis Spectrophotometer (JASCO Corporation, Tokyo, Japan) with Spectra Manager ${ }^{\mathrm{TM}}$ software [46].

\subsection{Determination of the Tannin Content}

As per our previous study [46], the tannin content was determined using a three-phase procedure: determination of TPC in different UBDE extracts by the Folin-Ciocâlteu method, absorption of tannins on standardized hide-powder, and determination of the phenolic compounds in the solution remaining after the second phase. The quantification of the molybdenum oxide's blue coloration intensity was determined by spectrophotometry at $760 \mathrm{~nm}$, and the difference between both determinations even represents the tannin content [46].

\subsection{Antimicrobial Activity}

The antibacterial and antifungal activities were evaluated by an adapted disc diffusion method from the Clinical and Laboratory Standard Institute (CLSI) [90,91].

\subsubsection{Microorganisms and Media}

All microorganism strains were obtained from the American Type Culture Collection (ATCC) for our study. They were identified at the Department of Microbiology and Immunology, Faculty of Dental Medicine, Ovidius University of Constanta. The Grampositive bacteria were Staphylococcus aureus (ATCC 29213), Enterococcus casseliflavus (ATCC 700327), Streptococcus pyogenes (ATCC 19615), Streptococcus pneumoniae (ATCC 49619), and the group of Gram-negative bacteria included Escherichia coli (ATCC 25922), Klebsiella pneumoniae (ATCC 13883), and Pseudomonas aeruginosa (ATCC 27853). The antifungal activity evaluation was performed using Candida albicans (ATCC 14053) and Candida parapsilosis (ATCC 22019).

Mueller-Hinton agar with 5\% defibrinated sheep blood (Thermo Fisher Scientific, $\mathrm{GmbH}$, Dreieich, Germany) was used as a culture medium for both Streptococcus sp. [90]. The other bacterial strains were maintained in Mueller Hinton agar (Thermo Fisher, Dreieich, Germany). For both Candida sp., Sabouraud 4\% Glucose Agar (Merk KGaA, Darmstadt, Germany) was selected as the culture medium.

\subsubsection{Inoculum Preparation}

The bacteria inoculum was prepared by the direct colony suspension method (CLSI) [90]. Thus, a $0.9 \%$ saline suspension of bacterial colonies selected from a $24 \mathrm{~h}$ agar plate was performed, according to the $0.5 \mathrm{McF}$ arland standard, with around $10^{8} \mathrm{CFU} / \mathrm{mL}$ (CFU = colonyforming unit) [90]. The yeast inoculum was prepared using the same method, adjusting the saline suspension of fungal colonies to the $0.5 \mathrm{McFarland}$ standard, with $10^{6} \mathrm{CFU} / \mathrm{mL}$ [92]. 


\subsubsection{Disc Diffusion Method}

Usnea barbata dry extracts and usnic acid were dissolved in $0.1 \%$ DMSO and applied on Whatman ${ }^{\circledR}$ filter paper discs (6 mm, Merk KGaA, Darmstadt, Germany). The solvent $(0.1 \%$ DMSO) was the negative control and UA in $0.1 \%$ DMSO $(129 \mathrm{mg} / \mathrm{mL})$ was the positive control for UBDE [46]. The weighted mass values for UA and each UBDE were similar to those used in our previous study to evaluate their cytotoxic activity by brine shrimp lethality assay [46]. Therefore, the concentrations of the sample UBDE solutions were as follows: $172 \mathrm{mg} / \mathrm{mL}$ UBEA, $162 \mathrm{mg} / \mathrm{mL}$ UBA, $161 \mathrm{mg} / \mathrm{mL}$ UBE and UBM, and $160 \mathrm{mg} / \mathrm{mL}$ UBW [46]. Each filter paper disc was impregnated with $10 \mu \mathrm{L}$ solution. For antimicrobial activity evaluation, blank antibiotic discs $(6 \mathrm{~mm})$-Levofloxacin $5 \mu \mathrm{g}$, Tetracycline $30 \mu \mathrm{g}$, and antifungal ones-Voriconazole $1 \mu \mathrm{g}$ and Fluconazole $15 \mu \mathrm{g}$ (Oxoid, Thermo Fisher Scientific $\mathrm{GmbH}$, Dreieich, Germany) were used. The blank discs were maintained in a freezer at $-14{ }^{\circ} \mathrm{C}$ and incubated at room temperature for $2 \mathrm{~h}$ before analysis.

Each inoculum was applied with a sterile cotton swab over the entire surface of the plate with the suitable culture media. After $15 \mathrm{~min}$ of drying, the filter paper discs were applied to the inoculated plates. The plates were incubated for $24 \mathrm{~h}$ at $37^{\circ} \mathrm{C}$.

\subsubsection{Reading Plates}

Examining the plates after $24 \mathrm{~h}$, circular zones of a microorganism growing inhibition around several discs could be observed. The results of the disc diffusion assay are expressed in the inhibition zone size (IZs) diameter, measured in $\mathrm{mm}$. IZs values [90] quantify the level of susceptibility of microbial strains after $24 \mathrm{~h}$ incubation.

\subsubsection{Interpretation of DDM Results}

Usnic acid and UBDE IZs were compared to the IZs values of the positive controls represented by the blank antibiotic/antifungal discs. In DDM, IZs values inversely correlate with minimum inhibitory concentrations (MIC) from standard dilution tests [90]. According to CLSI, the interpretive categories are as follows: Susceptible ("S"), Intermediate = dosedependent susceptibility ("I"), and Resistant (“R") [90].

\subsubsection{Data Analysis, Software}

The analyses were performed in triplicate, and the results are expressed as mean $(\mathrm{n}=3) \pm \mathrm{SD}$, calculated by Microsoft 365 Office Excel. The $p$-values were determined with the one-way ANOVA test. The differences between the mean values were considered significant when the $p$-value was $<0.05$.

\section{Conclusions}

Our study's novelty consists of ICP-MS analysis of 23 metals of Usnea barbata (L.) F.H. Wigg. from an unpolluted zone in the Călimani Mountains, Romania. The obtained data were analyzed in correlation with the specific properties of this lichen habitat zone and the trace/heavy metal content in the soil. Moreover, we compared the heavy metal content in $U$. barbata with permissible limits of toxic elements and found that only mercury was over the limit mentioned in the European Pharmacopoeia for medicinal plants.

Another original aspect of our research involves evaluation and comparative analysis of the antimicrobial actions of usnic acid and five dry extracts of $U$. barbata in different solvents against various pathogens known for their resistance to common antibacterial and antifungal drugs.

The obtained results could enrich the existing information in the scientific databaseswhich must be constantly updated-by the metal content and antimicrobial potential of autochthonous lichen from a peat bog zone of the highest Romanian volcanic mountains.

The antimicrobial study highlights that usnic acid and various $U$. barbata dry extracts (except water extract) have proven significant antibacterial and antifungal activities. The most susceptible microorganisms were Gram-positive bacteria. The antimicrobial potential of $U$. barbata dry extracts also demonstrates a moderate correlation with metabolite content. 
Our results suggest that further research can be aimed at advanced studies on the antibacterial and antifungal potential. Future studies could decipher the biochemical mechanisms and establish suitable doses of $\mathcal{U}$. barbata extracts for an optimal antimicrobial effect.

Supplementary Materials: The following are available online at https: / www.mdpi.com/article/ 10.3390/plants11010032/s1: Figure S1. Calibrations curves for 23 elements analyzed in U. barbata dried lichen using ICP-MS; Table S1. Specificity of ICP-MS elemental analysis, for two U. barbata (dUB) sample dilutions $(\mathrm{d}=10$ and $d=100)$, and $(n=3)$ replicates; Spike recovery (\%) values for all 23 elements; Table S2. Determination of the detection limit value (LOD) for each element in ICP-MS analysis of Usnea barbata dried lichen; Table S3. ICP-MS Standard solutions; Table S4. Preparation of (E1-E5) calibration standard solutions; Table S5. Calibration curve range, $\mathrm{R}^{2}$, LOD, and LOQ ( $\mu \mathrm{g} / \mathrm{L}$ and $\mu \mathrm{g} / \mathrm{g}$ ) for each element.

Author Contributions: Conceptualization, V.P., E.I.C. and V.B.; methodology, L.B., S.I.C., E.I.C., T.C., D.R., C.E.G. and V.B.; software, V.P. and S.I.C.; validation, S.I.C., E.I.C., T.C., D.R. and V.B.; formal analysis, L.B.; investigation, A.C.; resources, V.P., L.B., V.S. and C.E.G.; data curation, V.S.; writingoriginal draft preparation, V.P. and S.I.C.; writing-review and editing, V.P., D.G., G.V. and L.B.; visualization, L.B., C.E.G., D.G., G.V. and V.B.; supervision, L.B., C.E.G., D.G., G.V. and V.B.; project administration, V.B.; funding acquisition, V.P. All authors have read and agreed to the published version of the manuscript.

Funding: This work is supported by the project ANTREPRENORDOC, in the framework of the Human Resources Development Operational Programme 2014-2020, financed from the European Social Fund under the contract number 36355/23.05.2019 HRD OP/380/6/13-SMIS Code: 123847.

Institutional Review Board Statement: Not applicable.

Informed Consent Statement: Not applicable.

Data Availability Statement: Data are contained within the article and supplementary materials.

Acknowledgments: This study was performed in collaboration with the Research Center for Instrumental Analysis SCIENT, Tancabesti, Ilfov, Romania, and the Department of Pharmacognosy, Phytochemistry, and Phytotherapy, Faculty of Pharmacy, Carol Davila University of Medicine and Pharmacy, Bucharest, Romania.

Conflicts of Interest: The authors declare no conflict of interest.

\section{References}

1. Veeresham, C. Natural products derived from plants as a source of drugs. J. Adv. Pharm. Technol. Res. 2012, 3, 200-201. [CrossRef]

2. Nunes, V.; Mendez-Sanchez, N. Impact of Herbal and Dietary Supplements Causing Drug-Induced Liver Injury in Latin America. Clin. Liver Dis. 2020, 16, 83-86. [CrossRef] [PubMed]

3. Gilbert, B.; Ferreira, J.L.P.; Beatriz, M.; Carvalho, E.S.; Cascon, V.; Rocha, L.M. The official use of medicinal plants in public health. Cienc. Cult. 1997, 49, 339-344.

4. Bačkor, M.; Fahselt, D. Lichen photobionts and metal toxicity. Symbiosis 2008, 46, 1-10.

5. Ranković, B. Lichen Secondary Metabolites: Bioactive Properties and Pharmaceutical Potential; Springer: Cham, Switzerland, 2015; pp. 1-29.

6. White, P.A.S.; Oliveira, R.C.M.; Oliveira, A.P.; Serafini, M.R.; Araújo, A.A.S.; Gelain, D.P.; Moreira, J.C.F.; Almeida, J.R.G.S.; Quintans, J.S.S.; Quintans-Junior, L.J.; et al. Antioxidant activity and mechanisms of action of natural compounds isolated from lichens: A systematic review. Molecules 2014, 19, 14496-14527. [CrossRef] [PubMed]

7. Calcott, M.J.; Ackerley, D.F.; Knight, A.; Keyzers, R.A.; Owen, J.G. Secondary metabolism in the lichen symbiosis. Chem. Soc. Rev. 2018, 47, 1730-1760. [CrossRef]

8. Bačkor, M.; Loppi, S. Interactions of lichens with heavy metals. Biol. Plant. 2009, 53, 214-222. [CrossRef]

9. Conti, M.E.; Tudino, M.B. Lichens as Biomonitors of Heavy-Metal Pollution. Compr. Anal. Chem. 2016, 73, 118-149.

10. Smykla, J.; Szarek-Gwiazda, E.; Krzewicka, B. Trace elements in the lichens Usnea aurantiacoatra and Usnea antarctica from the vicinity of Uruguay's Artigas research station on King George Island, Maritime Antarctic. Pol. Bot. Stud. 2005, 19, 49-57.

11. Caridi, F.; D’Agostino, M.; Messina, M.; Marcianò, G.; Grioli, L.; Belvedere, A.; Marguccio, S.; Belmusto, G. Lichens as environmental risk detectors. Eur. Phys. J. Plus 2017, 132, 189. [CrossRef]

12. Ramzaev, V.; Barkovsky, A.; Gromov, A.; Ivanov, S.; Kaduka, M. Epiphytic fruticose lichens as biomonitors for retrospective evaluation of the 134Cs/137Cs ratio in Fukushima fallout. J. Environ. Radioact. 2014, 138, 177-185. [CrossRef]

13. Richardson, D.H. Metal uptake in lichens. Symbiosis 1995, 18, 119-127. 
14. Paukov, A.; Teptina, A.; Morozova, M.; Kruglova, E.; Favero-Longo, S.E.; Bishop, C.; Rajakaruna, N. The effects of edaphic and climatic factors on secondary lichen chemistry: A case study using saxicolous lichens. Diversity 2019, 11, 94. [CrossRef]

15. Sueoka, Y.; Sakakibara, M.; Sano, S.; Yamamoto, Y. A new method of environmental assessment and monitoring of Cu, Zn, As, and $\mathrm{Pb}$ pollution in surface soil using terricolous fruticose lichens. Environments 2016, 3, 35. [CrossRef]

16. Cobbett, C.; Goldsbrough, P. Phytochelatins and metallothioneins: Roles in heavy metal detoxification and homeostasis. Annu. Rev. Plant Biol. 2002, 53, 159-182. [CrossRef]

17. Pawlik-Skowrońska, B.; Purvis, O.W.; Pirszel, J.; Skowroński, T. Cellular mechanisms of Cu-tolerance in the epilithic lichen Lecanora polytropa growing at a copper mine. Lichenologist 2006, 38, 267-275. [CrossRef]

18. Purvis, O.W. Adaptation and interaction of saxicolous crustose lichens with metals. Bot. Stud. 2014, 55, 23. [CrossRef]

19. Pawlik-Skowrońska, B.; Bačkor, M. Zn/Pb-tolerant lichens with higher content of secondary metabolites produce less phytochelatins than specimens living in unpolluted habitats. Environ. Exp. Bot. 2011, 72, 64-70.

20. Paoli, L.; Grassi, A.; Vannini, A.; Maslaňáková, I.; Bil'ová, I.; Bačkor, M.; Corsini, A.; Loppi, S. Epiphytic lichens as indicators of environmental quality around a municipal solid waste landfill (C Italy). Waste Manag. 2015, 42, 67-73. [CrossRef]

21. Nikalje, G.C.; Suprasanna, P. Coping with metal toxicity-Cues from halophytes. Front. Plant Sci. 2018, 9, 777. [CrossRef]

22. Kováčik, J.; Dresler, S.; Peterková, V.; Babula, P. Metal-induced oxidative stress in terrestrial macrolichens. Chemosphere 2018, 203, 402-409. [CrossRef]

23. Mitrović, T.; Stamenković, S.; Cvetković, V.; Tošić, S.; Stanković, M.; Radojević, I.; Stefanović, O.; Čomić, L.; Dačić, D.; Ćurčić, M.; et al. Antioxidant, antimicrobial and antiproliferative activities of five lichen species. Int. J. Mol. Sci. 2011, 12, 5428-5448. [CrossRef]

24. Elix, J.A.; Stocker-Wörgötter, E. Biochemistry and secondary metabolites. In Lichen Biology, 3rd ed.; Nash, T.H., Ed.; Cambridge University Press: Cambridge, UK, 2008; pp. 104-133.

25. Jacopin, E.; Lehtinen, S.; Débarre, F.; Blanquart, F. Factors favouring the evolution of multidrug resistance in bacteria. J. R. Soc. Interface 2020, 17, 20200105. [CrossRef]

26. Anand, U.; Nandy, S.; Mundhra, A.; Das, N.; Pandey, D.K.; Dey, A. A review on antimicrobial botanicals, phytochemicals and natural resistance modifying agents from Apocynaceae family: Possible therapeutic approaches against multidrug resistance in pathogenic microorganisms. Drug Resist. Updat. 2020, 51, 100695. [CrossRef]

27. Blanco, P.; Hernando-Amado, S.; Reales-Calderon, J.A.; Corona, F.; Lira, F.; Alcalde-Rico, M.; Bernardini, A.; Sanchez, M.B.; Martinez, J.L. Bacterial multidrug efflux pumps: Much more than antibiotic resistance determinants. Microorganisms 2016, 4, 14. [CrossRef] [PubMed]

28. Alves-Barroco, C.; Rivas-García, L.; Fernandes, A.R.; Baptista, P.V. Tackling Multidrug Resistance in Streptococci-From Novel Biotherapeutic Strategies to Nanomedicines. Front. Microbiol. 2020, 11, 579916. [CrossRef]

29. Nasir, N.S.M.; Chan, Y.Y.; Harun, A.; Husin, A.; Kamaruzzaman, N.F.; Wada, Y.; Abdul-Rahman, Z. Linezolid-Resistant Enterococcus casseliflavus and Enterococcus gallinarum isolated from poultry farms in Kelantan, Malaysia. Malays. J. Microbiol. 2021, $17,361-368$.

30. Verma, R.; Baroco, A.L. Enterococcus casseliflavus septicaemia associated with hepatobiliary infection in a 75-year-old man. BMJ Case Rep. 2017, 2017, 219636.

31. Behera, I.C.; Swain, S.K.; Sahu, M.C. Colonization and antibiotic resistance dynamics of patients at intensive care unit: Our experience. Asian J. Pharm. Clin. Res. 2017, 10, 417-421.

32. Yang, Y.; Li, X.; Zhang, Y.; Liu, J.; Hu, X.; Nie, T.; Yang, X.; Wang, X.; Li, C.; You, X. Characterization of a hypervirulent multidrugresistant ST23 Klebsiella pneumoniae carrying a blaCTX-M-24 IncFII plasmid and a pK2044-like plasmid. J. Glob. Antimicrob. Resist. 2020, 22, 674-679. [CrossRef]

33. Binder, U.; Arastehfar, A.; Schnegg, L.; Hörtnagl, C.; Hilmioğlu-Polat, S.; Perlin, D.S.; Lass-Flörl, C. Efficacy of lamb against emerging azole-and multidrug-resistant Candida parapsilosis isolates in the Galleria mellonella model. J. Fungi 2020, 6, 377. [CrossRef]

34. Dandapat, M.; Paul, S. Secondary metabolites from lichen Usnea longissima and its pharmacological relevance. Pharmacogn. Res. 2019, 11, 103-109.

35. Behera, B.C.; Verma, N.; Sonone, A.; Makhija, U. Antioxidant and antibacterial properties of some cultured lichens. Bioresour. Technol. 2008, 99, 7424. [CrossRef]

36. Idamokoro, E.M.; Masika, P.J.; Muchenje, V.; Falta, D.; Green, E. In-vitro antibacterial sensitivity of Usnea barbata lichen extracted with methanol and ethyl-acetate against selected Staphylococcus species from milk of cows with mastitis. Arch. Anim. Breed. 2014, 57, 1-9. [CrossRef]

37. Popovici, V.; Bucur, L.; Popescu, A.; Caraiane, A.; Badea, V. Determination of the content in usnic acid and polyphenols from the extracts of Usnea barbata L. and the evaluation of their antioxidant activity. Farmacia 2018, 66, 337-341.

38. Prateeksha; Paliya, B.S.; Bajpai, R.; Jadaun, V.; Kumar, J.; Kumar, S.; Upreti, D.K.; Singh, B.N.R.; Nayaka, S.; Joshi, Y.; et al. The genus Usnea: A potent phytomedicine with multifarious ethnobotany, phytochemistry and pharmacology. RSC Adv. 2016, 6, 21672-21696. [CrossRef]

39. Basiouni, S.; Fayed, M.A.A.; Tarabees, R.; El-Sayed, M.; Elkhatam, A.; Töllner, K.R.; Hessel, M.; Geisberger, T.; Huber, C.; Eisenreich, W.; et al. Characterization of sunflower oil extracts from the lichen Usnea barbata. Metabolites 2020, 10, 353. [CrossRef] 
40. Salgado, F.; Albornoz, L.; Cortéz, C.; Stashenko, E.; Urrea-Vallejo, K.; Nagles, E.; Galicia-Virviescas, C.; Cornejo, A.; Ardiles, A.; Simirgiotis, M.; et al. Secondary Metabolite Profiling of Species of the Genus Usnea by UHPLC-ESI-OT-MS-MS. Molecules 2018, 23, 54. [CrossRef] [PubMed]

41. Popovici, V.; Bucur, L.; Vochita, G.; Gherghel, D.; Mihai, C.T.; Rambu, D.; Calcan, S.I.; Costache, T.; Cucolea, I.E.; Matei, E.; et al. In vitro anticancer activity and oxidative stress biomarkers status determined by usnea barbata (L.) f.h. wigg. dry extracts. Antioxidants 2021, 10, 1141. [CrossRef] [PubMed]

42. Bubach, D.F.; Catán, S.P.; Messuti, M.I.; Arribére, M.A.; Guevara, S.R. Bioaccumulation of trace elements in lichens exposed to geothermal and volcanic activity from copahue-caviahue volcanic complex, patagonia, Argentina. Ann. Environ. Sci. Toxicol. 2020, 4, 5-15.

43. Cazacu, B.C.; Buzgar, N.; Iancu, O.G. Geochemical and spatial distribution of heavy metals in forest soils adjacent to the Tinovul Mare Poiana Stampei peat bog. Rev. Chim. 2018, 69, 434-438. [CrossRef]

44. Cansaran, D.; Kahya, D.; Yurdakulol, E.; Atakol, O. Identification and quantitation of usnic acid from the lichen Usnea species of anatolia and antimicrobial activity. Z. Naturforsch. C J. Biosci. 2006, 61, 773-776. [CrossRef] [PubMed]

45. Joshi, D.R.; Adhikari, N. An Overview on Common Organic Solvents and Their Toxicity. J. Pharm. Res. Int. 2019, 28, 1-18. [CrossRef]

46. Popovici, V.; Bucur, L.; Popescu, A.; Schröder, V.; Costache, T.; Rambu, D.; Cucolea, I.E.; Gîrd, C.E.; Caraiane, A.; Gherghel, D.; et al. Antioxidant and cytotoxic activities of Usnea barbata (L.) F.H. Wigg. dry extracts in different solvents. Plants 2021, 10, 909. [CrossRef] [PubMed]

47. Conti, M.E.; Finoia, M.G.; Bocca, B.; Mele, G.; Alimonti, A.; Pino, A. Atmospheric background trace elements deposition in Tierra del Fuego region (Patagonia, Argentina), using transplanted Usnea barbata lichens. Environ. Monit. Assess. 2012, 184, 527-538. [CrossRef]

48. Conti, M.E.; Plà, R.; Simone, C.; Jasan, R.; Finoia, M.G. Implementing the monitoring breakdown structure: Native lichens as biomonitors of element deposition in the southern Patagonian forest connected with the Puyehue volcano event in 2011-a 6-year survey (2006-2012). Environ. Sci. Pollut. Res. 2020, 27, 38819-38834. [CrossRef] [PubMed]

49. Pino, A.; Alimonti, A.; Conti, M.E.; Bocca, B. Iridium, platinum and rhodium baseline concentration in lichens from Tierra del Fuego (South Patagonia, Argentina). J. Environ. Monit. 2010, 12, 1857-1863. [CrossRef]

50. Zambrano, A.; Nash, T.H. Lichen responses to short-term transplantation in Desierto de los Leones, Mexico City. Environ. Pollut. 2000, 107, 407-412. [CrossRef]

51. Białońska, D.; Dayan, F.E. Chemistry of the lichen Hypogymnia physodes transplanted to an industrial region. J. Chem. Ecol. 2005, 31, 2975-2991. [CrossRef]

52. Bergamaschi, L.; Rizzio, E.; Giaveri, G.; Loppi, S.; Gallorini, M. Comparison between the accumulation capacity of four lichen species transplanted to a urban site. Environ. Pollut. 2007, 148, 468-476. [CrossRef]

53. Meli, M.A.; Desideri, D.; Cantaluppi, C.; Ceccotto, F.; Feduzi, L.; Roselli, C. Elemental and radiological characterization of commercial Cetraria islandica (L.) Acharius pharmaceutical and food supplementation products. Sci. Total Environ. 2018, 613-614, 1566-1572. [CrossRef]

54. Zhao, Y.; Wang, M.; Xu, B. A comprehensive review on secondary metabolites and health-promoting effects of edible lichen. J. Funct. Foods 2021, 80, 104283. [CrossRef]

55. Marinescu, E.; Elisei, A.M.; Aprotosoaie, A.C.; Cioancă, O.; Trifan, A.; Miron, A.; Robu, S.; Ifrim, C.; Hăncianu, M. Assessment of heavy metals content in some medicinal plants and spices commonly used in Romania. Farmacia 2020, 68, 1099-1105. [CrossRef]

56. Luo, L.; Wang, B.; Jiang, J.; Fitzgerald, M.; Huang, Q.; Yu, Z.; Li, H.; Zhang, J.; Wei, J.; Yang, C.; et al. Heavy Metal Contaminations in Herbal Medicines: Determination, Comprehensive Risk Assessments, and Solutions. Front. Pharmacol. 2021, $11,595335$. [CrossRef]

57. Osmani, M.; Bani, A.; Hoxha, B. Heavy Metals and Ni Phytoextractionin in the Metallurgical Area Soils in Elbasan. Albanian J. Agric. Sci. 2015, 14, 414-419.

58. Shirkhanloo, H.; Mirzahosseini, S.A.H.; Shirkhanloo, N.; Ali Moussavi-Najarkola, S.; Farahani, H. The evaluation and determination of heavy metals pollution in edible vegetables, water and soil in the south of Tehran province by GIS. Arch. Environ. Prot. 2015, 41, 64-74. [CrossRef]

59. Simkova, K.; Polesny, Z. Ethnobotanical review of wild edible plants used in the Czech Republic. J. Appl. Bot. Food Qual. 2015, 88, $49-67$.

60. Dobrescu, D.; Tanasescu, M.; Mezdrea, A.; Ivan, C.; Ordosch, E.; Neagoe, F.; Rizeanu, A.; Trifu, L.; Enescu, V. Contributions to the complex study of some lichens-Usnea genus. Pharmacological studies on Usnea barbata and Usnea hirta species. Rom. J. Physiol. 1993, 30, 101-107.

61. Li, S.M.; Fang, Y.; Ning, H.M.; Wu, Y.X. Heavy metals in Chinese therapeutic foods and herbs. J. Chem. Soc. Pak. 2012, 34, 1091-1095.

62. Bud'ová, J.; Bačkor, M.; Bačkorová, M.; Židzik, J. Usnic acid and copper toxicity in aposymbiotically grown lichen photobiont Trebouxia erici. Symbiosis 2006, 42, 169.

63. Bačkorová, M.; Jendželovský, R.; Kello, M.; Bačkor, M.; Mikeš, J.; Fedoročko, P. Lichen secondary metabolites are responsible for induction of apoptosis in HT-29 and A2780 human cancer cell lines. Toxicol. Vitr. 2012, 26, 462-468. [CrossRef] [PubMed] 
64. Antonenko, Y.N.; Khailova, L.S.; Rokitskaya, T.I.; Nosikova, E.S.; Nazarov, P.A.; Luzina, O.A.; Salakhutdinov, N.F.; Kotova, E.A. Mechanism of action of an old antibiotic revisited: Role of calcium ions in protonophoric activity of usnic acid. Biochim. Biophys. Acta-Bioenerg. 2019, 1860, 310-316. [CrossRef]

65. Chelombitko, M.A.; Firsov, A.M.; Kotova, E.A.; Rokitskaya, T.I.; Khailova, L.S.; Popova, L.B.; Chernyak, B.V.; Antonenko, Y.N. Usnic acid as calcium ionophore and mast cells stimulator. Biochim. Biophys. Acta-Biomembr. 2020, 1862, 183303. [CrossRef] [PubMed]

66. Bouarab-Chibane, L.; Forquet, V.; Lantéri, P.; Clément, Y.; Léonard-Akkari, L.; Oulahal, N.; Degraeve, P.; Bordes, C. Antibacterial properties of polyphenols: Characterization and QSAR (Quantitative structure-activity relationship) models. Front. Microbiol. 2019, 10, 829. [CrossRef]

67. Bansal, S.; Choudhary, S.; Sharma, M.; Kumar, S.S.; Lohan, S.; Bhardwaj, V.; Syan, N.; Jyoti, S. Tea: A native source of antimicrobial agents. Food Res. Int. 2013, 53, 568-584. [CrossRef]

68. Navarro-Martínez, M.D.; García-Cánovas, F.; Rodríguez-López, J.N. Tea polyphenol epigallocatechin-3-gallate inhibits ergosterol synthesis by disturbing folic acid metabolism in Candida albicans. J. Antimicrob. Chemother. 2006, 57, 1083-1092. [CrossRef]

69. Sieniawska, E. Activities of tannins-From in Vitro studies to clinical trials. Nat. Prod. Commun. 2015, 10, 1877-1884. [CrossRef] [PubMed]

70. Scalbert, A. Antimicrobial properties of tannins. Phytochemistry 1991, 30, 3875-3883. [CrossRef]

71. Farha, A.K.; Yang, Q.Q.; Kim, G.; Li, H.B.; Zhu, F.; Liu, H.Y.; Gan, R.Y.; Corke, H. Tannins as an alternative to antibiotics. Food Biosci. 2020, 38, 100751. [CrossRef]

72. Jin, J.Q.; Rao, Y.; Bian, X.L.; Zeng, A.G.; Yang, G. De Solubility of (+)-usnic acid in water, ethanol, acetone, ethyl acetate and n-hexane. J. Solut. Chem. 2013, 42, 1018-1027. [CrossRef]

73. Jin, S.E.; Jin, H.E. Antimicrobial activity of zinc oxide nano/microparticles and their combinations against pathogenic microorganisms for biomedical applications: From physicochemical characteristics to pharmacological aspects. Nanomaterials 2021, 11, 263. [CrossRef] [PubMed]

74. Vincent, M.; Hartemann, P.; Engels-Deutsch, M. Antimicrobial applications of copper. Int. J. Hyg. Environ. Health 2016, 219, 585-591. [CrossRef]

75. Moshafi, M.H.; Ranjbar, M.; Ilbeigi, G. Biotemplate of albumen for synthesized iron oxide quantum dots nanoparticles (QDNPs) and investigation of antibacterial effect against pathogenic microbial strains. Int. J. Nanomed. 2019, 14, 3273-3282. [CrossRef]

76. Shrestha, G.; Raphael, J.; Leavitt, S.D.; St Clair, L.L. In vitro evaluation of the antibacterial activity of extracts from 34 species of North American lichens In vitro evaluation of the antibacterial activity of extracts from 34 species of North American lichens. Pharm. Biol. 2014, 52, 1262-1266. [CrossRef] [PubMed]

77. Jha, B.N.; Shrestha, M.; Pandey, D.P.; Bhattarai, T.; Bhattarai, H.D.; Paudel, B. Investigation of antioxidant, antimicrobial and toxicity activities of lichens from high altitude regions of Nepal. BMC Complement. Altern. Med. 2017, 17, 282. [CrossRef] [PubMed]

78. Kumar, S.N.; Mohandas, C. An Antifungal Mechanism of Protolichesterinic Acid from the Lichen Usnea albopunctata Lies in the Accumulation of Intracellular ROS and Mitochondria-Mediated Cell Death Due to Apoptosis in Candida tropicalis. Front. Pharmacol. 2017, 8, 301. [CrossRef]

79. Ranković, B.; Mišić, M.; Sukdolak, S. Antimicrobial activity of extracts of the lichens Cladonia furcata, Parmelia caperata, Parmelia pertusa, Hypogymnia physodes and Umbilicaria polyphylla. Biologia 2009, 64, 53-58. [CrossRef]

80. Sinha, S.N.; Biswas, M. Evaluation of antibacterial activity of some lichen from Ravangla, Sikkim, India. Int. J. Pharma Bio Sci. 2011, 2, 23-28.

81. Ranković, B.; Mišić, M.; Sukdolak, S.; Milosavljević, D. Antimicrobial activity of the lichens Aspicilia cinerea, Collema cristatum, Ochrolechia androgyna, Physcia aipolia and Physcia caesia. Ital. J. Food Sci. 2007, 19, 461-469.

82. Hanuš, L.O.; Temina, M.; Dembitsky, V.M. Antibacterial and antifungal activities of some phenolic metabolites isolated from the lichenized ascomycete Ramalina lacera. Nat. Prod. Commun. 2007, 16, 677-688. [CrossRef]

83. Ranković, B.; Kosanić, M.; Sukdolak, S. Antimicrobial activity of some lichens and their components. Recent Adv. Clin. Med. 2010, 279-286.

84. Rafika, B.; Monia, A.A. Antibacterial Activity of the Chloroform, Acetone, Methanol and queous Extracts of Algerian Lichens. Jordan J. Pharm. Sci. 2018, 11, 55-67.

85. Prabhu, S.S.; Sudha, S.S. Evaluation of the antibacterial properties of some Lichen species against human pathogens. Int. J. Adv. Res. Biol. Sci. 2015, 2, 177-181.

86. Randlane, T.; Tõrra, T.; Saag, A.; Saag, L. Key to European Usnea species. Bibl. Lichenol. 2009, 100, 419-462.

87. European Pharmacopoeia (Ph. Eur.) 10th Edition I EDQM-European Directorate for the Quality of Medicines. Available online: https:/ / www.edqm.eu/en/european-pharmacopoeia-ph-eur-10th-edition (accessed on 17 November 2021).

88. Wilschefski, S.C.; Baxter, M.R. Inductively Coupled Plasma Mass Spectrometry: Introduction to Analytical Aspects. Clin. Biochem. Rev. 2019, 40, 115-133. [CrossRef] [PubMed]

89. United States Environmental Protection Agency. Hazardous Waste Support Section SOP NO. HW-2b Revision 15 ICP-MS Data Validation; United States Environmental Protection Agency (USEPA): Washington, DC, USA, 2012; pp. 1-43. 
90. Kassim, A.; Omuse, G.; Premji, Z.; Revath, G. Comparison of Clinical Laboratory Standards Institute and European Committee on Antimicrobial Susceptibility Testing guidelines for the interpretation of antibiotic susceptibility at a University teaching hospital in Nairobi, Kenya: A cross-sectional study. Ann. Clin. Microbiol. Antimicrob. 2012, 15, 21. [CrossRef] [PubMed]

91. Hudzicki, J. Kirby-Bauer Disk Diffusion Susceptibility Test Protocol; American Society for Microbiology: Washington, DC, USA, 2009; pp. 1-23.

92. El-Mashad, N.; Foad, M.F.; Saudy, N.; Salem, D.A. Susceptibility tests of oropharyngeal Candida albicans from Egyptian patients to fluconazole determined by three methods. Braz. J. Microbiol. 2012, 43, 266-273. [CrossRef] [PubMed] 